This is the peer-reviewed version of the following article: Prado, V., Lence, E., Thompson, P., Hawkins, A., \& González-Bello, C. (2016). Freezing the Dynamic Gap for Selectivity: Motion-Based Design of Inhibitors of the Shikimate Kinase Enzyme. Chemistry - A European Journal, 22(50), 17988-18000, which has been published in final form at https://doi.org/10.1002/chem.201602923. This article may be used for non-commercial purposes in accordance with Wiley-VCH Terms and Conditions for Self-Archiving 


\title{
Freezing the Dynamic Gap for Selectivity - Motion-based Design of Inhibitors of the Shikimate Kinase Enzyme
}

\author{
Verónica Prado, ${ }^{[\mathrm{a}]}$ Emilio Lence, ${ }^{[\mathrm{a}]}$ Paul Thompson, ${ }^{[\mathrm{b}]}$ Alastair R. Hawkins ${ }^{[\mathrm{b}]}$ and Concepción González- \\ Bello*[a]
}

\begin{abstract}
Shikimate kinase (SK), the fifth enzyme of the aromatic amino acid biosynthesis, is a recognized target for antibiotic drug discovery. The potential of the distinct dynamic apolar gap, which isolates the natural substrate from the solvent environment for catalysis, and motion of Mycobacterium tuberculosis and Helicobacter pylori SK enzymes, which was observed by Molecular Dynamics simulation studies, was explored for inhibition selectivity. The results of our biochemical and computational studies reveal that the incorporation of bulky groups at position C5 of 5-aminoshikimic acid and the natural substrate enhances the selectivity for the $H$. pylori enzyme due to key motion differences in the shikimic acid binding domain (mainly helix $\alpha 5$ ). These studies show that the less exploited motion-based design approach, not only is an alternative strategy for the development of competitive inhibitors, but could also be a way to achieve selectivity against a particular enzyme among its homologous ones.
\end{abstract}

\section{Introduction}

Resistance to current antibiotics in pathogenic bacteria is a huge worldwide challenge in clinical settings because some pathogens have even become resistant to multiple types of antibiotics. $^{[1-8]}$ Of particular concern are patients with a weak immune system undergoing surgery, cancer chemotherapy and dialysis, amongst others, for whom our ability to deal with secondary infections is crucial. The increased occurrence of hard to treat bacterial infections has mainly been determined by: (1) the inappropriate and excessive use of these drugs in medicine, veterinary medicine and agriculture over the years; (2) the reduced output in the development of novel antibiotics by the pharmaceutical industry over the past decades; ${ }^{[9-10]}$ and (3) the inherent tendency of bacteria to survive in hostile environments. ${ }^{[11]}$ It is therefore a matter of urgency to develop

[a] V. Prado, Dr. E. Lence, Prof. C. González-Bello Centro Singular de Investigación en Química Biolóxica e Materiais Moleculares (CIQUS) and Departamento de Química Orgánica, Universidade de Santiago de Compostela calle Jenaro de la Fuente $\mathrm{s} / \mathrm{n}$, 15782 Santiago de Compostela, Spain E-mail: concepcion.gonzalez.bello@usc.es

[b] P. Thompson, Prof. A. R. Hawkins Institute of Cell and Molecular Biosciences, Medical School, University of Newcastle upon Tyne, Catherine Cookson Building, Framlington Place, Newcastle upon Tyne NE2 4HH, UK

Supporting information for this article is given via a link at the end of the document. new antibacterial agents and approaches to face the challenge of multidrug resistance.

In recent years a great deal of research has been devoted to the search for unexplored key bacterial functions for the development of novel antibiotics with a new mechanism of action. In particular, those proteins encoded by essential bacterial genes appear to be a good starting point for the design of compounds that deal with bacterial viability (antibiotics). Our research group is exploring the potential of shikimate kinase (SK, EC 2.7.1.71, aroK gene), the fifth enzyme of the aromatic amino acid biosynthesis, which is also known as the shikimic acid pathway. ${ }^{12}$ This enzyme attracted our attention because it has proved to be essential (aroK gene) in relevant pathogenic bacteria and it does not have any counterpart in human cells. ${ }^{13,14}$ SK is a recognized target for tuberculosis, infections caused by the ESKAPE pathogen Pseudomonas aeruginosa, which is nowadays resistant to almost all antibiotics, the foodborne diseases caused by Escherichia coli and for the treatment of Helicobacter pylori infections, which cause gastric and duodenal ulcers and in some cases stomach cancer.
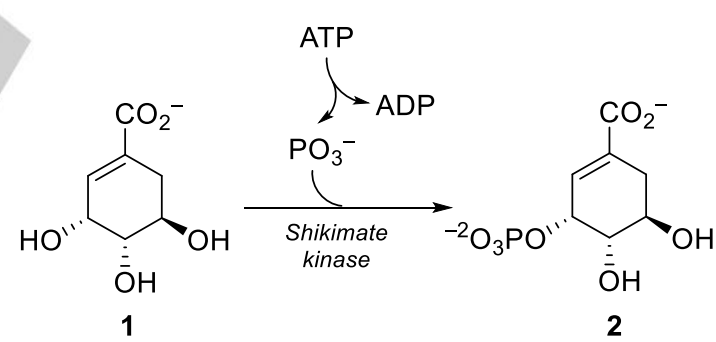

Scheme 1 Enzymatic conversion catalyzed by SK.

SK is a magnesium dependent enzyme that catalyzes the stereospecific phosphorylation of the C3 hydroxyl group of shikimic acid (1) to provide shikimate-3-phosphate (2) by using ATP as a cofactor (Scheme 1). By a combination of NMR and computational studies, we have shown recently that the conversion catalysed by SK involves a dissociative phosphoryltransfer mechanism. ${ }^{[15]}$ The reaction is initiated with the formation of a metaphosphate intermediate $\left(\mathrm{PO}_{3}{ }^{-}\right)$by cleavage of the $y$ O-P bond in ATP, followed by subsequent nucleophilic attack of the $\mathrm{C} 3$ hydroxyl group. SK has two binding sites, one for shikimic acid (1), and another for the cofactor (ATP), with different key interactions in both cases. SK has three domains: (1) the CORE domain that contains five stranded parallel $\beta$ sheets and the P-loop, which forms the binding site for ATP and ADP; (2) the LID domain, which closes over the active site and has residues that are essential for the binding of ATP and catalysis; and (3) the substrate binding (SB) domain, which is responsible for the recognition and binding of 1 . 
Most of the approaches used in the structure-based design of inhibitors of this enzyme (and for other targets) are based on docking or virtual screening studies using the available crystal structures. ${ }^{[16-19]}$ In this case, the disposable structures are binary complexes of the enzyme with one of the substrates (ATP or 1) in the active site or ternary complexes with shikimic acid (1) and ADP. ${ }^{[20-22]}$ As one would expect for enzyme complexes with the substrate(s) or product(s), these structures show a closed conformation of the active site. As a consequence, the outcomes of these studies are governed by this arrangement. In these cases, inhibition is achieved by ligands that stabilize the closed arrangement in a similar way to the Michaelis complex (ES). Therefore, the size and conformation of the ligands would be determined by the space available in the employed crystal structures. However, enzymes are 'dynamic' systems that are able to adopt diverse conformations during catalysis and this could also be exploited in inhibitor design since the flexibility is essential for catalysis. Thus, in the absence of substrate, they adopt an open conformation to receive the substrate to be transformed. Once the substrate enters the active site, a flexible substrate-covering loop closes the active site over the substrate for conversion. Finally, the product is expelled from the active site and the inactive open conformation is recovered to start the next cycle. It seems reasonable that for enzyme inhibitor design, in addition to stabilizing a closed disposition of the active site that prevents the entry of the substrate(s), disabling the closure of the active site for catalysis could also be an interesting alternative strategy. This motion-based approach allows the design of ligands that target additional cavities generated during this motion but have limited (or no) access in the closed conformation. The success of this approach could also benefit from the recent advances in computational methods that have consolidated their value as important complementary tools that can assist in the elucidation of the essential motions required for catalysis. By using this less exploited 'motion-based design approach', we report here competitive inhibitors of the SK enzyme that block the closure of the active site by reducing the flexibility of the LID and SB domains, which are required for catalytic turnover.

Recently, we reported our first approach to achieve the stabilization of the open conformation of the active site. ${ }^{[23]}$ This study was carried out with 5-O-benzyl-substituted shikimic acid derivatives $\mathbf{3 a}$ and $\mathbf{3 b}$, which bear 3-nitrobenzyl and 5benzo[b]thiophenylmethyl groups, respectively (Figure 1).

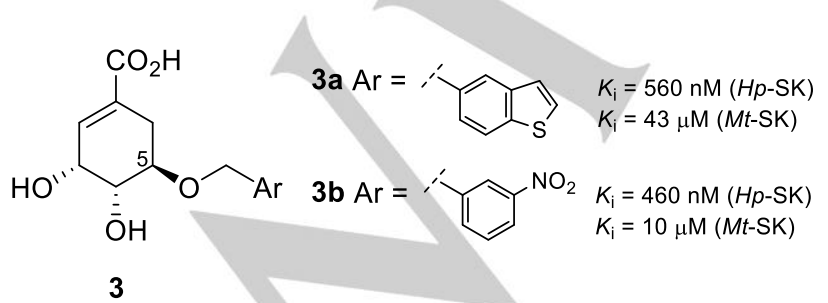

Figure 1 Selected 5-O-benzyl-substituted shikimic acid analogues reported previously as reversible competitive inhibitors. $K_{\mathrm{i}}$ against $H p$-SK and $M t-S K$ are also included.
These compounds proved to be reversible competitive inhibitors of SK from M. tuberculosis (SK-Mt) and from H. pylori (SK-Hp), with $K_{\mathrm{i}}$ values below $K_{\mathrm{m}}$, specifically $43 \mu \mathrm{M}$ and $10 \mu \mathrm{M}$ for SK-Mt and $560 \mathrm{nM}$ and $460 \mathrm{nM}$ for SK-Hp, respectively. In both cases the aromatic moiety was incorporated to interact with the dynamic apolar pocket generated by several lipophilic residues located in $\alpha$-helices $\alpha 2, \alpha 3$ and $\alpha 5$ (SB domain) surrounding the C5 hydroxyl group of $\mathbf{1}$, which isolates the natural substrate from the solvent environment (Figure 2).
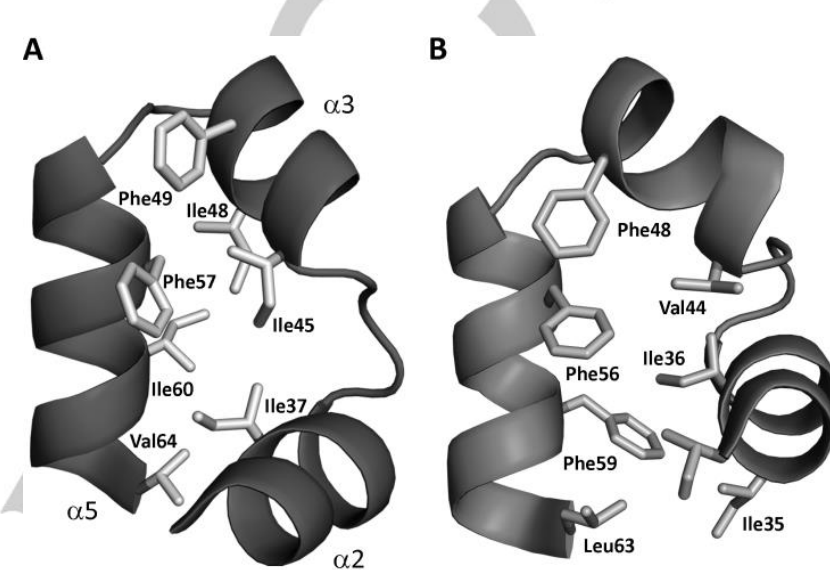

Figure 2 Detail view of the apolar pocket in the SB domain of the Mt-SK (A) and Hp-SK (B) enzymes. Relevant side chain residues are shown and labelled.

On studying the essential motion of the SK-Mt and SK-Hp enzymes by Molecular Dynamic (MD) simulation studies on the enzyme product complexes (SK/ADP/2) (Figure 3), ${ }^{[23-24]}$ we observed that: (1) as expected, a large opening of the LID domain (up to $10 \AA$ ) is required in both cases; (2) surprisingly, an opening of the SB domain, which is composed of three $\alpha$ helices ( $\alpha 2, \alpha 3$ and $\alpha 5)$, is also necessary in the two enzymes; and (3) more importantly, there are significant differences in the opening of the SB domain between the two enzymes (Figures $3 A$ and $3 C$ vs $3 B$ and $3 D$ ). Moreover, the examination of the vibrational modes calculated by using principal component analysis as implemented in Amber also showed these clear differences (Figures 3E vs 3F) (see experimental section and Figure S1). A synchronous and large opening of the three $\alpha$ helices $\alpha 2(\sim 7 \AA), \alpha 3(\sim 10 \AA)$ and $\alpha 5(\sim 6 \AA)$ takes place for the $\mathrm{Mt}$-SK enzyme, but for the Hp-SK enzyme an asynchronous and more reduced opening was observed, mainly in helix $\alpha 5$. In addition, for Mt-SK the process is very fast since in less than $\sim 3$ ns at $25{ }^{\circ} \mathrm{C}$ the product is released from the active site, but for $\mathrm{Hp}$-SK the process is very slow as large changes are not observed until over $\sim 20 \mathrm{~ns}$ after heating at $50 \stackrel{\circ}{\circ}$. These findings suggest that: (1) the opening of the LID and SB domains is wide enough to accommodate bulky groups in position $\mathrm{C} 5$ of shikimic acid (1) and this is able to promote extra binding interactions with this important part of the active site and may provide inhibitors with improved inhibitory potencies; and (2) these modifications would be more efficient for the $H$. pylori enzyme. 
A
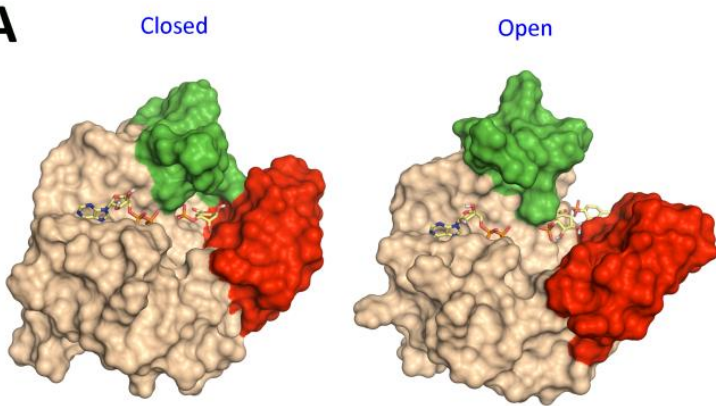

C

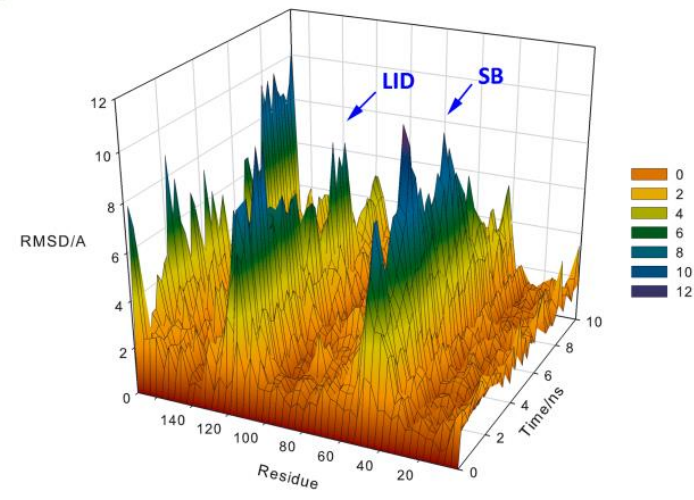

E

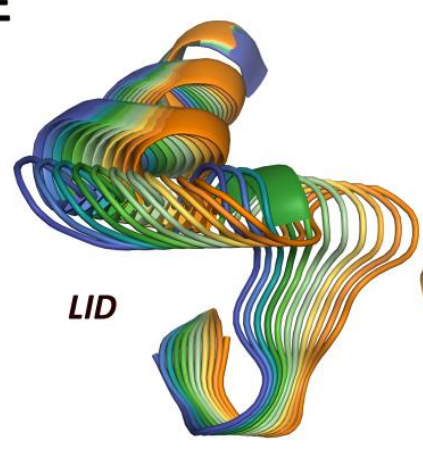

B

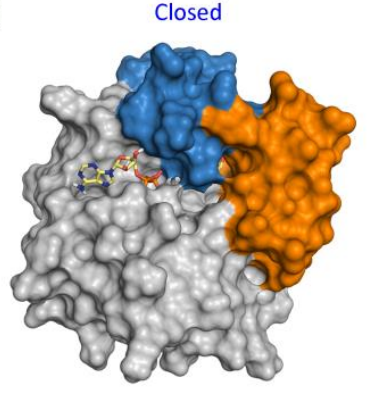

D
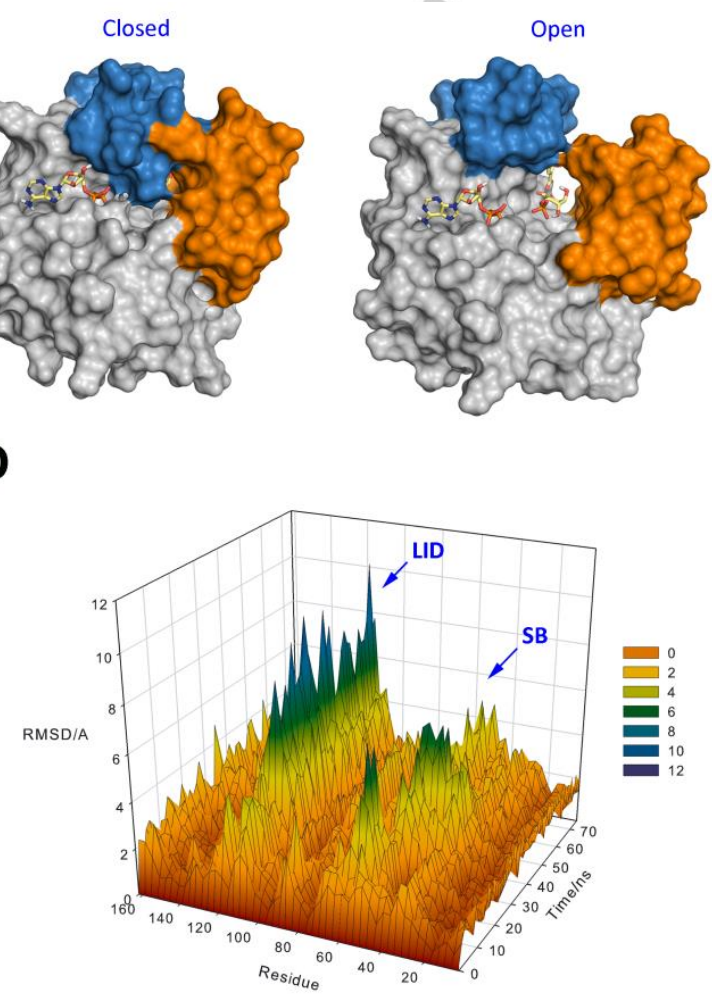

$\mathbf{F}$

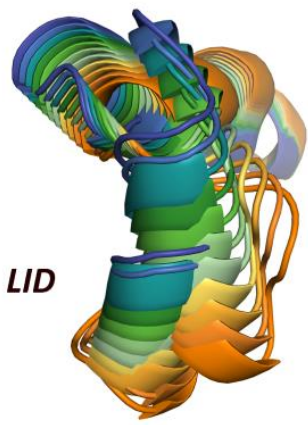

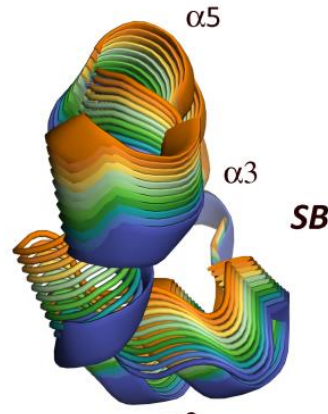

$\alpha 2$

Figure 3 Shikimate kinase motion. $(A, B)$ Overall view of the motion required for product release from the active site of $M t-S K(A)$ and $H p$-SK $(B)$ obtained by $M D$ simulation studies. The position of 2 at the beginning and the end of the simulation is shown. Significant changes were not observed in the position of ADP. The LID and SB domains of Mt-SK (A, green and red, respectively) and of $H p$-SK (B, blue and orange, respectively) are highlighted. (C,D) RMSD plots for the protein backbone (Ca, C, N, and O atoms) calculated per residue in the Hp-SK/ADP/2 (A) and Mt-SK/ADP/2 (B) complexes obtained from MD simulations studies. (E,F) Overall view of the SK motion obtained by examination of the vibrational modes. The main vibrational modes for $M t-S K(E)$ and $H p$-SK (F) enzymes are presented.

To explore this hypothesis, we report here the synthesis and inhibitory properties against $\mathrm{Mt}$-SK and $\mathrm{Hp}$-SK of several $\mathrm{N}, \mathrm{N}$ dibenzyl-5-aminoshikimic acid analogues, namely compounds $\mathbf{4}$, that incorporate two aromatic moieties at $\mathrm{C} 5$ of 5 -aminoshikimic acid (Figure 4). The corresponding $N$-benzyl-5-amino derivatives (compounds 5) were also synthesized to evaluate the effect of replacing an ether linkage by an amine one in 3 . The binding modes of the reported compounds with the two SK enzymes were initially studied using GOLD $5 .{ }^{2[25]}$ and diverse open forms of the active site obtained by MD simulations studies. The stability was then further analyzed by MD simulation studies.

\section{Results and Discussion}

\section{Synthesis of Compounds 4-5}

The synthesis of $N, N$-di(benzo[b]thiophen-5-ylmethyl)amine derivative $\mathbf{4 a}, \mathrm{N}, \mathrm{N}$-di(naphth-2-ylmethyl)amine derivative $\mathbf{4 b}$ and $\mathrm{N}, \mathrm{N}$-di(3-bromo-1H-indol-5-ylmethyl)amine derivative $\mathbf{4 d}$ was 
carried by alkylation of amine 7 as outlined in Scheme 2 . Staudinger reduction of azide $6^{[23]}$ provided amine 7 , which was treated with 5-(bromomethyl)benzo[b]thiophene, 2bromomethylnaphthalene, or tert-butyl 5-(bromomethyl)- $1 \mathrm{H}$ indole-1-carboxylate in the presence of potassium carbonate to give the dialkyl derivatives 8 . Finally, deprotection of the methyl ester afforded the desired compounds 4 .<smiles>O=C(O[Na])C1=C[C@@H](O)[C@H](O)[C@H](N(C[Ga])CBr)C1</smiles>

4<smiles>[Al]=C[Te]Cc1ccc2sccc2c1</smiles>

a<smiles>O=C(O[Na])C1=C[C@@H](O)[C@H](O)[C@H](NCBr)C1</smiles>

5<smiles>Cc1ccc2[nH]cc(Cl)c2c1</smiles>

c $\mathrm{G}=\mathrm{H}$

d $\mathrm{G}=\mathrm{Br}$<smiles>ICc1ccc2ccccc2c1</smiles>

b against $M t$-SK, compound $\mathbf{4 d}\left(K_{\mathrm{i}}=8.2 \mu \mathrm{M}\right)$, was the worst against $H p$-SK $\left(K_{\mathrm{i}}=8.7 \mu \mathrm{M}\right)$. In an effort to obtain further details of the binding interactions responsible for the inhibitory activity and to gain a better understanding of this trend, the binding modes of compounds 4-5 with $\mathrm{Mt}$-SK and $\mathrm{Hp}$-SK were studied. The results of these studies are discussed below.

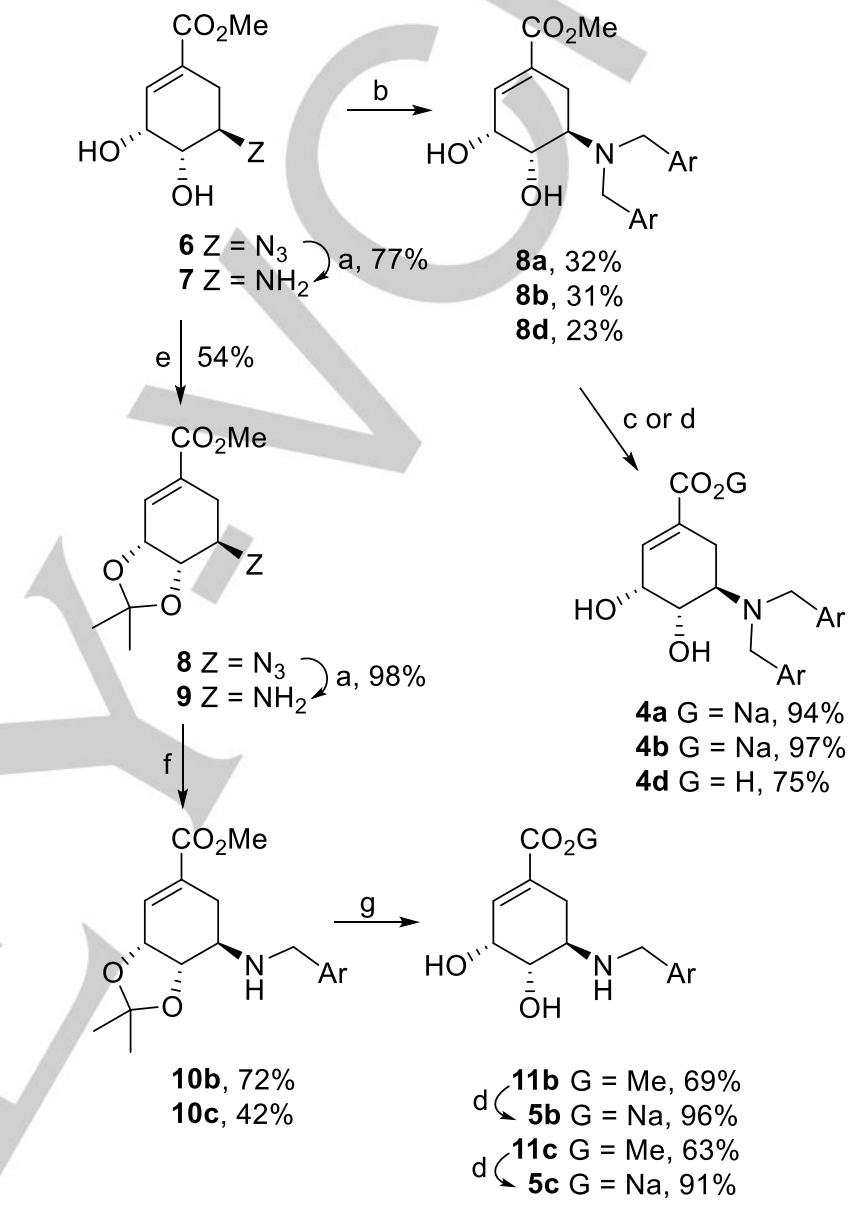

Scheme 2 Synthesis of compounds 4-5. Reagents and conditions: (a) $\mathrm{PPh}_{3}, \mathrm{H}_{2} \mathrm{O}$, THF, $\triangle$. (b) $\mathrm{ArCH}_{2} \mathrm{Br}, \mathrm{K}_{2} \mathrm{CO}_{3}, \mathrm{CH}_{3} \mathrm{CN}, \mathrm{RT}$. (c) $\mathrm{K}_{2} \mathrm{CO}_{3}, \mathrm{MeOH}$ (aq, $75 \%$ ), $\Delta$. (d) $\mathrm{NaOH}, \mathrm{THF}, \mathrm{RT}$. (e) $\mathrm{Me}_{2} \mathrm{C}(\mathrm{OMe})_{2}, \mathrm{CSA}, \Delta$. (f) $\mathrm{ArCHO}$, $\mathrm{NaBH}_{3} \mathrm{CN}, \mathrm{NaOAc}, 4 \AA \mathrm{MS}, \mathrm{MeOH}, \mathrm{RT}$. (g) $\mathrm{HCl}(6 \mathrm{M}), \mathrm{EtOH}, 60 \stackrel{\circ}{ }$.

\section{Binding Mode}

Molecular docking using GOLD $5.2^{[25]}$ was initially carried out with diverse inactive open forms of the SK active site, which were obtained from several poses of the MD simulation of: (a) $H p-S K / A D P / 2 \quad(50 \quad n s)^{[23]}$ and (b) Mt-SK/ATP/(6R)-6hydroxyshikimic acid (10 ns). ${ }^{[24]}$ Poses in which the LID and SB domains were open, but in which the essential arginine for substrate recognition, Arg132/Arg136 (in $H$. pylori and $M$. tuberculosis, respectively), had not suffered large displacements were chosen. Specifically, snapshots from the 10-20 ns period of (a) and the 5-7 ns of (b) were selected. The proposed binding modes were further analyzed by MD simulation studies (50 ns). against $M t$-SK, i.e, compound $\mathbf{4 b}\left(K_{i}=48 \mu \mathrm{M}\right)$ with naphthalene moiety, proved to be the most potent against $\mathrm{Hp}$ SK $\left(K_{\mathrm{i}}=300 \mathrm{nM}\right)$. At the same time, the most potent inhibitor 
Table 1. $K_{\mathrm{i}}(\mu \mathrm{M})$ values for compounds 3-5 against $H p$-SK and $M t-S K^{[a]}$

\begin{tabular}{lllll}
\hline Entry & Compd & \multicolumn{1}{c}{ Ar } & Hp-SK & Mt-SK \\
\hline $1^{24}$ & 3a & $\begin{array}{l}\text { benzo[b]thiophen-5- } \\
\text { yl }\end{array}$ & $0.56 \pm 0.05$ & $43 \pm 1$ \\
$2^{24}$ & 3c & naphth-2-yl & $1.80 \pm 0.10$ & $22 \pm 1$ \\
3 & 4a & $\begin{array}{l}\text { benzo[b]thiophen-5- } \\
\text { yl }\end{array}$ & $5.20 \pm 0.40$ & $24 \pm 2$ \\
4 & 4b & naphth-2-yl & $0.30 \pm 0.02$ & $48 \pm 5$ \\
5 & 4d & (3-bromo)indol-5-yl & $8.70 \pm 0.50$ & $8.20 \pm 0.40$ \\
6 & 5b & naphth-2-yl & $181 \pm 11$ & $>2000$ \\
7 & 5c & indol-5-yl & $455 \pm 5$ & $>2000$ \\
\hline
\end{tabular}

[a] Assay conditions: Tris. $\mathrm{HCl}(100 \mathrm{mM}, \mathrm{pH}$ 7.7), ATP (2.5 mM), NADH (0.2 $\mathrm{mM})$, PEP $(1 \mathrm{mM}), \mathrm{MgCl}_{2}(5 \mathrm{mM}), \mathrm{KCl}(0.1 \mathrm{M})$, lactate dehydrogenase (2 units), pyruvate kinase $(2.8$ units $), 25 \stackrel{\circ}{\circ} \mathrm{C} . K_{\mathrm{m}}(\mathbf{1}, M t-S K)=544 \mu \mathrm{M} . K_{\mathrm{m}}(\mathbf{1}$, $H p-S K)=39 \mu \mathrm{M}$.

The replacement of the ether linkage in compounds 3 by an $\mathrm{NH}$ linkage (secondary amine), which should improve the solubility of the compounds in water, provided ligand poses in which the benzyl moiety was located close to Asp33/Asp34 (in $\mathrm{H}$. pylori and $M$. tuberculosis, respectively). Based on the results of structural studies it was suggested that this residue would act as a general base to deprotonate the C3 hydroxyl group in $\mathbf{1}$ for nucleophilic attack. ${ }^{[20]}$ This behaviour of compounds $\mathbf{5}$ is due to an electrostatic interaction between the protonated amino group of the ligands and the carboxylate group of Asp33/Asp34. As a consequence, the benzyl moieties would be located outside the apolar pocket as desired. On the other hand, $\mathrm{N}, \mathrm{N}$-dibenzylamine derivatives 4 were found to bind in the active site of the two SK enzymes, with the aromatic moiety interacting with the apolar pocket of the SB domain as desired. It is important to highlight that the incorporation of a second benzyl group on the C5 nitrogen atom in $\mathbf{5}$ is crucial, not only to establish extra apolar interactions within the pocket, but also to lower the basicity of the amino group and therefore avoid protonation under neutral conditions. A positive charge would not be stabilized by this apolar pocket (Figure 2).

The results of our computational studies reveal that $N, N$ dibenzylamine derivatives $\mathbf{4}$ would stabilize a very open conformation of the LID and SB domains (Figure 5). The analysis of the variation of the relative distance between selected residues in the LID and SB domains in the $\mathrm{Hp}$ $\mathrm{SK} / \mathrm{ATP} / \mathrm{Mg}^{2+} / \mathbf{L}(\mathrm{L}=\mathbf{3 a}$ and $\mathbf{4 b})$ and $M t-S K / A T P / \mathrm{Mg}^{2+} / \mathbf{L}(\mathrm{L}=\mathbf{3 b}$ and 4d) complexes during the whole MD simulation shows that compounds $\mathbf{4}$ stabilize a more open conformation of the two domains than previously reported inhibitors $\mathbf{3 a}$ and $\mathbf{3 b}$. For $\mathrm{Hp}$ SK, Arg116, Pro117 and Leu118 located in the LID domain and Arg45, Phe48, Glu53 and Glu49 of the SB domain were selected (Figure 5A). For Mt-SK, Arg117, Pro118 and Leu119 located in the LID domain and Ile45, Ala46, Phe49 and Glu54 of the SB domain were selected (Figure 5B). Moreover, the analysis of the root-mean-square deviations (RMSD) for the protein backbone $\left(\mathrm{C}^{\alpha}, \mathrm{C}, \mathrm{N}\right.$, and $\mathrm{O}$ atoms) calculated in the SK/ATP/Mg ${ }^{2+} / 4$ complexes obtained from MD simulations studies revealed their stability (Figure S2).

Remarkably, the stabilization of the open conformation by $N, N$ dibenzylamine derivatives 4 occurs in quite distinct manners for the two enzymes (Figure 6). In general, for the Mt-SK enzyme, the two aromatic rings would be located in close proximity and act as separating clamps for the two domains. In contrast, for the Hp-SK enzyme, one of the aromatic rings would be located in the base of the active site and the other between the two domains in an arrangement similar to the wings of a butterfly. We consider that these differences are a consequence of the intrinsically different motions of the two enzymes and therefore of the dissimilar 'generated gap' that is achieved when the active site opens. As mentioned previously, whereas the active site of $M t$-SK opens like an accordion for product release, the $\mathrm{H}$. pylori site undergoes a much smaller twist that mainly involves $\alpha$-helix a5. This causes a significant difference in the available 'generated gap'. The fact that the least potent inhibitor of the $\mathrm{N}, \mathrm{N}$-dibenzylamine series against $\mathrm{Mt}$-SK, i.e., compound $\mathbf{4 b}\left(K_{\mathrm{i}}\right.$ $=48 \mu \mathrm{M})$, is the most potent one against $H p$-SK $\left(K_{\mathrm{i}}=300 \mathrm{nM}\right)$ can be explained by this distinct binding mode, as discussed below.
A

C

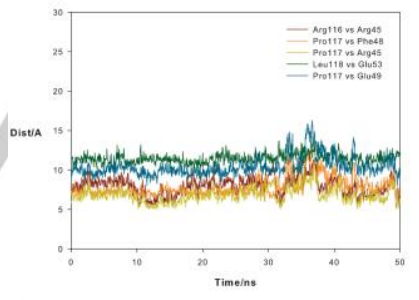

$\mathbf{E}$

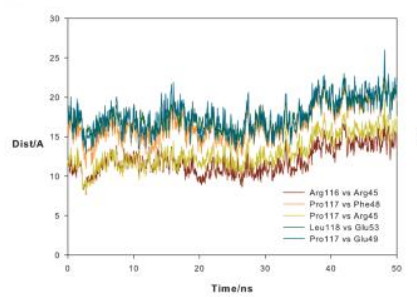

$\mathbf{F}$
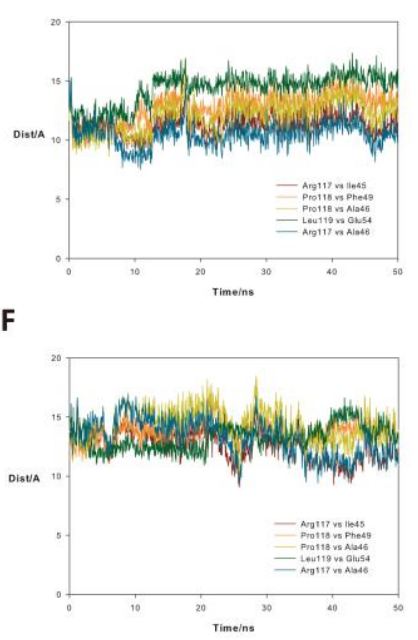

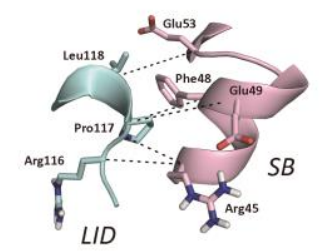

Figure 5 Variation of the relative distance between the LID and SB domains in the $H p$-SK/ATP/Mg $/ \mathrm{Mg}^{2+} / 3 \mathbf{a}(\mathrm{C}), \mathrm{Hp}$-SK/ATP/Mg $/ \mathrm{Mg}^{2+} / \mathbf{b}$ (E), Mt-SK/ATP/ $/ \mathrm{Mg}^{2+} / 3 \mathbf{b}$ (D) and $M t-S K / A T P / M^{2+} / 4 d(F)$ enzyme complexes during whole simulation. (A) For $\mathrm{Hp}$-SK, the distances were calculated between the CA atoms of Arg116 and Arg45, the CA atoms of Pro117 and Phe48, the N atom of Pro117 and the CA atom of Arg45, the CA atoms of Leu118 and Glu53 and the CA atoms of Pro117 and Glu49. (B) For Mt-SK, the distances were calculated between the CA atoms of Arg117 and lle45, the CA atoms of Pro118 and Phe49, the N atom of Pro118 and the CA atom of Ala46, the CA atoms of Leu119 and Glu54 and the CA atoms of Arg117 and Ala46. 
A

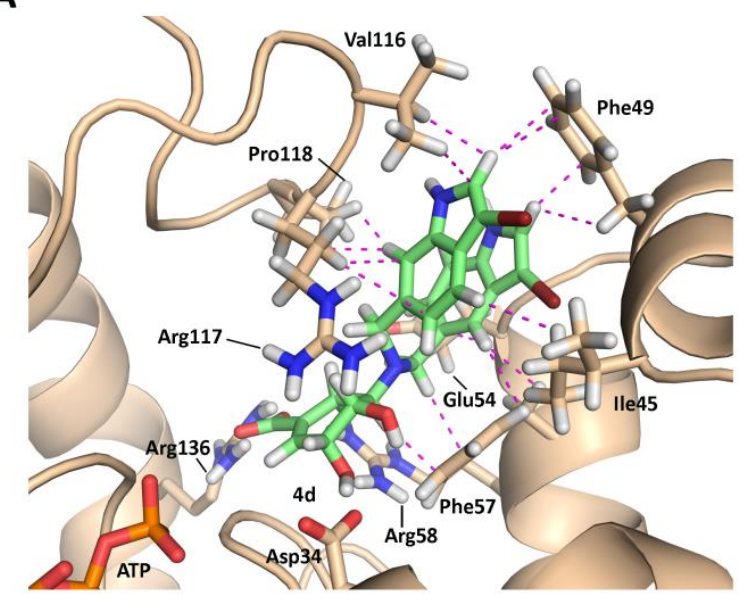

C

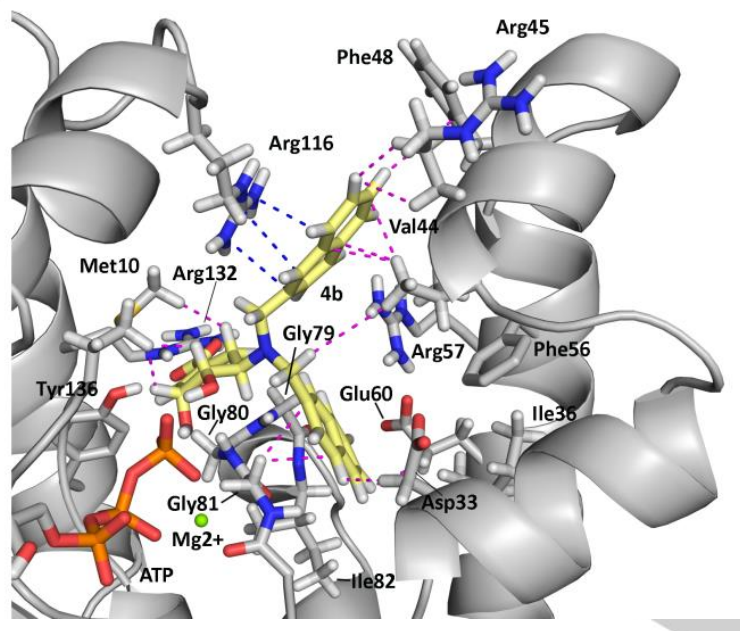

B

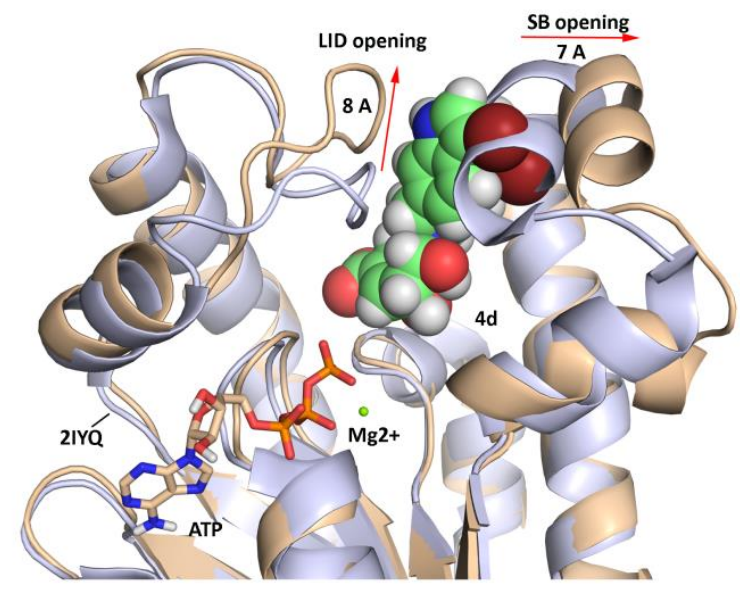

D

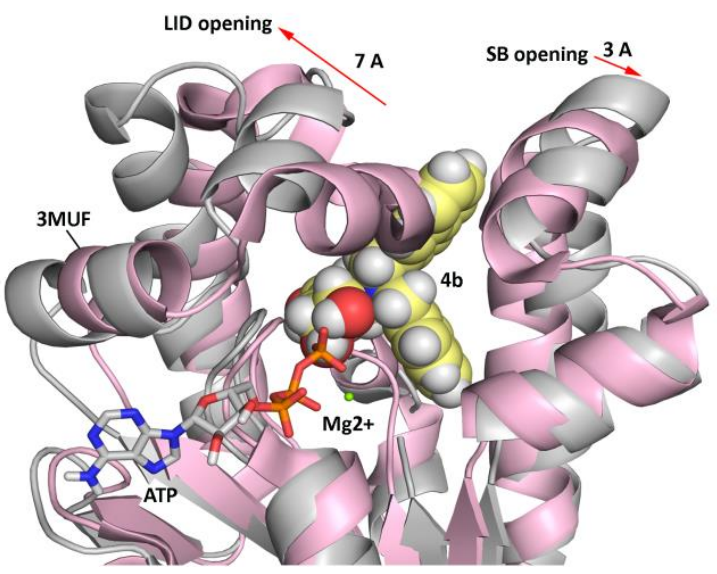

Figure 6 Binding mode of $N, N$-dibenzylamino derivatives $4 d(A, B)$ and $4 \mathbf{b}(C, D)$ obtained by docking and MD simulation studies in the active site of $M t$-SK (wheat) and Hp-SK (gray) enzymes, respectively. The poses showed for ligands $\mathbf{4 d}$ and $\mathbf{4 b}$ correspond to snapshots after $30 \mathrm{~ns}$ of MD simulation. (B,D) Conformational changes in the LID and SB domains of the SK enzymes caused by the binding of compounds $\mathbf{4 d}$ and $\mathbf{4 b}$. The closed active form [PDB codes 2 IYQ (Mt-SK) and 3MUF ( $H p-S K)]$ and the inactive open arrangement of the SK enzymes are compared. Relevant side chain residues are shown and labelled. Cation- $\pi$ (blue) and lipophilic (magenta) interactions between ligands and the enzyme residues are shown.

The binding mode of the most potent inhibitor against Mt-SK, compound $\mathbf{4 d}$, is shown in Figures $6 \mathrm{~A}$ and $6 \mathrm{~B}$. The two indole moieties in $\mathbf{4} \mathbf{d}$ would intercalate the LID and SB domains. This is achieved by a set of favourable lipophilic interactions with several apolar residues within the two domains. In particular, $\mathbf{4 d}$ interacts with the side chains of Pro118, Val116 and Arg117, which are located in the LID, and with Phe49, lle45, Phe57 and Glu54, which are located in the SB domain. The aromatic moieties would be located between Arg117 and Glu54. The essential arginine would interact with one of these aromatic rings, mainly by $\mathrm{CH}-\pi$ interactions between the Arg117 carbon side chain and the indole ring, and the second one would have apolar interactions with the carbon side chain of Glu54. Cation- $\pi$ interactions between the guanidinium group of Arg117 and the indole rings were not observed for $\mathbf{4 d}$. Moreover, unlike $N, N$ dinaphthylamine derivative $\mathbf{4 b}$ and $\mathrm{N}, \mathrm{N}$-dibenzothiophenylamine derivative $\mathbf{4 a}$, which proved to be about 6 -fold and 3 -fold less potent than $\mathbf{4 d}$, respectively, the position of the indole moieties is very stable during the simulation, which might account for the higher inhibitory potency. The binding free energies were calculated using the MM/PBSA ${ }^{[26]}$ approach in implicit water (generalized Born, GB) as implemented in Amber. Compound $4 \mathbf{d}$ has a binding free energy that is $-11.7 \mathrm{kcal}$ and $-8.7 \mathrm{kcal}$ lower than those of $\mathbf{4 b}$ and $\mathbf{4 a}$, respectively (Table S1). It seems that the inductive effect resulting from the incorporation of the bromo-substituent in the $\mathrm{C} 3$ position of the indole ring enhances the binding affinity with the aforementioned residues, in particular with the essential arginine. 
The $N, N$-dinaphthylamine derivative $\mathbf{4 b}$ would bind in the active site of the Hp-SK enzyme with one of the naphthalene moieties located in the base of the active site and the other positioned between the LID and SB domains (Figures 6C and 6D). The position of the latter is controlled by a strong cation- $\pi$ interaction with the essential arginine in addition to several apolar contacts with Phe48, Val44 ( $\mathrm{CH}-\pi)$ and Arg45 (carbon chain). The second aromatic ring would be surrounded by favourable apolar interactions with several conserved residues of the active site. Specifically, this unit interacts with the main chain of Gly79, Gly80 and Gly81, the carbon side chains of Asp33 and Glu60 and the side chain of lle82. Moreover, the C3, C4 and $\mathrm{C} 5 \mathrm{CH}$ groups on the cyclohexene ring in $\mathbf{4 b}$ would establish several apolar interactions with the side chain of Met10. All of these favourable interactions anchor the ligand in the active site and fix the open inactive conformation of the active site, which remains stable during the whole simulation. The key interaction that explains the marked increase in the inhibitory potency of compound $\mathbf{4 b}\left(K_{\mathrm{i}}=300 \mathrm{nM}\right)$ when compared with the other two analogues of the series $\left(K_{\mathrm{i}}=8.7-5.2 \mu \mathrm{M}\right)$ is not only the interaction with the essential arginine but also the large conformational change that positions its guanidinium group far from the centre of recognition of the cofactor. The calculated free energies also showed a good correlation with the experimental data. For instance, compound $\mathbf{4 b}$ has a binding free energy that is $-12.3 \mathrm{kcal}$ lower than that of $\mathbf{4 d}$ (Table S1).

\section{Conclusions and Final Remarks}

Diverse reversible competitive inhibitors of shikimate kinase - a recognized target for antibiotic drug discovery against relevant pathogenic bacteria - were designed based on the essential enzyme motion. The potential of the distinct 'generated apolar gap' and motion of $M$. tuberculosis and $H$. pylori shikimate kinase enzymes, which was observed in previously reported MD simulation studies of the enzyme/products complexes, ${ }^{[23]}$ was explored for inhibitor design and selectivity. To this end, several 5 -aminoshikimic acid derivatives that incorporate one or two bulky groups in the C5 amino group were synthesized and tested against the two enzymes.

Compounds 4, which contain an $\mathrm{N}, \mathrm{N}$-dibenzylamine moiety, were the best inhibitors for both enzymes but with different trends for the two SK. N,N-Dinaphthylamine derivative $4 \mathbf{b}$ was the most potent for the $\mathrm{Hp}$-SK enzyme, with a $K_{\mathrm{i}}$ value of $300 \mathrm{nM}$ This represents an improvement on the previous results obtained with shikimic acid derivatives $\mathbf{3 a}$ and $\mathbf{3 b}$, which bear an $O$-benzyl group in position $\mathrm{C} 5$, and $\mathbf{4 b}$ is the most potent inhibitor reported to date against the SK enzyme. For the Mt-SK enzyme, the $N, N$-diindolylamine derivative $4 \mathbf{d}$ was the best compound, with a $K_{\mathrm{i}}$ value of $8.2 \mu \mathrm{M}$, and this has similar inhibition potency as previously reported 3-nitrobenzyl derivative 3b. In contrast, replacement of the ether linkage in $\mathbf{3}$ by an amino one, compounds 5 , causes a large decrease in inhibitory potency. The incorporation of the second benzyl group on the C5 nitrogen atom in $\mathbf{5}$ is crucial, not only to establish extra apolar interactions within the pocket, but also to lower the basicity of the amino group and therefore avoid protonation under neutral conditions. Compound $\mathbf{4 b}$ is 160-fold higher inhibitory potency against $\mathrm{Hp}$-SK than $\mathrm{Mt}$-SK.

Docking and MD simulation studies were performed in order to provide some rationale for the relative potencies of the inhibitors, the trends observed and to obtain further details of the binding mode of the inhibitors. The $\mathrm{N}, \mathrm{N}$-dibenzylamine derivatives 4 would stabilize an open conformation of the LID and SB domains, albeit in quite a distinct manner for the two enzymes. Whereas for Mt-SK the two aromatic rings would bind in the active site with the two aromatic rings in close proximity and acting as separating clamps of the two domains, in the case of $\mathrm{Hp}$-SK one of the aromatic rings would be located in the base of the active site and the other between the two domains. In both cases, however, the interaction of the essential arginine with only one of the aromatic rings through a set of favourable apolar interactions with this 'dynamic apolar pocket' seems to be crucial to enhance the inhibition potency of the ligands.

The results of our biochemical and computational studies reveal that the more parsimonious motion and the narrow opening of the SB domain of $H p$-SK, mainly focused in helix $\alpha 5$, makes this motion-based design approach with the scaffold identified here, compounds 4, more efficient for the $H$. pylori enzyme than for the M. tuberculosis one. The more limited flexibility of the SB domain in $\mathrm{Hp}$-SK, i.e., its lower induced-fit adaptability, favours the conformational changes resulting from the incorporation of bulky groups at position C5 of the natural substrate having a more pronounced effect. Taking into account our MD simulation studies, which show that for the Mt-SK enzyme the opening of the active site takes place in a similar way to the movement of an accordion, the incorporation of additional apolar groups in the scaffold reported here should provide more potent inhibitors against the $M$. tuberculosis enzyme. Studies to validate this hypothesis are currently in progress in our laboratories. These studies also show that the motion-based design, not only is a good and alternative strategy for the development of competitive inhibitors, but could also be a strategy to achieve selective inhibitors against a certain enzyme among its homologous ones. By using this approach, (1) the presence in the selected pocket of residues with markedly different properties would not be required, and (2) as the essential motion for catalysis is blocked, the effects of changes on residues to avoid the inhibition (resistance) should have a less pronounced effect. It is important to highlight that the apolar pocket surrounding the C4 and C5 hydroxyl groups of the natural substrate targeted in this approach is quite conserved (Figure 2).

\section{Experimental Section}

General. All starting materials and reagents were commercially available and were used without further purification unless is indicated. ${ }^{1} \mathrm{H}$ NMR spectra $(250,300$ and $500 \mathrm{MHz})$ and ${ }^{13} \mathrm{C}$ NMR spectra $(63,75$ and 125 $\mathrm{MHz}$ ) were measured in deuterated solvents. $J$ values are given in Hertz. NMR assignments were carried out by a combination of $1 \mathrm{D}, \mathrm{COSY}$, and DEPT-135 experiments. FT-IR spectra were recorded as $\mathrm{NaCl}$ plates or $\mathrm{KBr}$ discs in a PerkinElmer Two FTIR spectrometer with attenuated total reference. $[\alpha]_{\mathrm{D}}^{20}=$ values are given in $10^{-1} \mathrm{deg} \mathrm{cm}^{2} \mathrm{~g}^{-1}$. MilliQ deionized 
water was used in all the buffers. All procedures involving the use of ionexchange resins were carried out at room temperature using Milli-Q deionized water. Amberlite IR-120 $\left(\mathrm{H}^{+}\right)$(cation exchanger) was washed alternately with water, $10 \% \mathrm{NaOH}$, water, $10 \% \mathrm{HCl}$, and finally water before use. The spectroscopic measurements were made on a Varian Cary 100 UV-Vis spectrophotometer with a $1 \mathrm{~cm}$ path length cell fitted with a Peltier temperature controller.

Methyl (3R,4S,5R)-5-azido-3,4-(O-isopropyliden)cyclohex-1-ene-1carboxylate (7) - To a stirred solution of 2,2-dimethoxypropane $(12 \mathrm{~mL}$, $4.69 \mathrm{mmol}$ ) and camphorsulfonic acid (109 $\mathrm{mg}, 0.47 \mathrm{mmol})$, under argon and at room temperature, diol $6(1.0 \mathrm{~g}, 4.69 \mathrm{mmol})$ was added. The resulting mixture was stirred at room temperature for $4 \mathrm{~h}$, diluted with diethyl ether and neutralized with saturated $\mathrm{NaHCO}_{3}$. The organic layer was separated and the aqueous layer was extracted with diethyl ether $(\times 3)$. The combined organic extracts were dried (anh. $\mathrm{Na}_{2} \mathrm{SO}_{4}$ ), filtered and concentrated under reduced pressure. The resulting residue was purified by flash chromatography, eluting with (30:70) ethyl acetate/hexane, to give acetal $7(635 \mathrm{mg}, 54 \%)$, as a colorless oil. $[\alpha]_{\mathrm{D}}^{20}=$

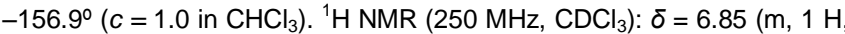
$\mathrm{H} 2), 4.63(\mathrm{~m}, 1 \mathrm{H}, \mathrm{H} 3), 4.06(\mathrm{dd}, J=6.2$ and $8.0 \mathrm{~Hz}, 1 \mathrm{H}, \mathrm{H} 4), 3.70(\mathrm{~s}, 3$ $\left.\mathrm{H}, \mathrm{OCH}_{3}\right), 3.60$ (td, $J=4.7$ and $\left.8.5 \mathrm{~Hz}, 1 \mathrm{H}, \mathrm{H} 5\right), 2.72(\mathrm{dd}, J=4.7$ and $17.6 \mathrm{~Hz}, 1 \mathrm{H}, \mathrm{H6}$ ax) 2.14 (ddd, $J=2.0,9.0$ and $17.6 \mathrm{~Hz}, 1 \mathrm{H}, \mathrm{H6}$ eq) 1.38 (s, $\left.3 \mathrm{H}, \mathrm{CH}_{3}\right)$ and $1.32\left(\mathrm{~s}, 3 \mathrm{H}, \mathrm{CH}_{3}\right)$ ppm. ${ }^{13} \mathrm{C} \mathrm{NMR}\left(63 \mathrm{MHz}, \mathrm{CDCl}_{3}\right) \delta$ : $165.9(\mathrm{C}), 134.0(\mathrm{C}), 130.5(\mathrm{CH}), 110.0(\mathrm{C}), 76.4(\mathrm{CH}), 71.6(\mathrm{CH}), 59.3$ $(\mathrm{CH}), 52.1\left(\mathrm{OCH}_{3}\right), 27.8\left(\mathrm{CH}_{3}\right), 26.9\left(\mathrm{CH}_{2}\right)$ and $25.6\left(\mathrm{CH}_{3}\right)$ ppm. IR (ATR): $v=2104\left(\mathrm{~N}_{3}\right)$ and $1710(\mathrm{CO}) \mathrm{cm}^{-1}$. MS (ESI) $\mathrm{m} / z=276\left(\mathrm{MNa}^{+}\right)$ HRMS calcd for $\mathrm{C}_{11} \mathrm{H}_{15} \mathrm{~N}_{3} \mathrm{O}_{4} \mathrm{Na}\left(\mathrm{MNa}^{+}\right)$: 276.0955; found, 276.0948

Methyl (3R,4S,5R)-5-amino-3,4-(O-isopropyliden)cyclohex-1-ene-1carboxylate (8) - A solution of azide 7 (635 mg, $2.51 \mathrm{mmol})$ in tetrahydrofuran $(63 \mathrm{~mL})$ and water $(0.61 \mathrm{~mL})$ was treated with triphenylphosphine $(726 \mathrm{mg}, 2.74 \mathrm{mmol})$. The resulting mixture was heated at reflux for $4 \mathrm{~h}$. After cooling to room temperature, the solvent was removed under reduced pressure and the resulting residue was purified by flash chromatography, eluting with (10:90) methanol/dichloromethane, to give amine $8(570 \mathrm{mg}, 98 \%)$, as a yellow oil. $[\alpha]_{\mathrm{D}}^{20}=-749.5^{\circ}\left(c=1.0\right.$ in $\left.\mathrm{CHCl}_{3}\right) .{ }^{1} \mathrm{H}$ NMR $\left(250 \mathrm{MHz}, \mathrm{CDCl}_{3}\right) \delta: 6.77$ $(\mathrm{m}, 1 \mathrm{H} ; \mathrm{H} 2), 4.54$ (t, $J=4.6 \mathrm{~Hz}, 1 \mathrm{H} ; \mathrm{H} 3), 3.79(\mathrm{dd}, J=6.4$ and $7.8 \mathrm{~Hz}, 1$ $\mathrm{H}$; H4), 3.62 (s, $3 \mathrm{H} ; \mathrm{OCH}_{3}$ ), 2.88 (td, $J=4.6$ and 8.4, $1 \mathrm{H} ; \mathrm{H} 5$ ), 2.55 (dd, $J=4.5$ and $17.5 \mathrm{~Hz}, 1 \mathrm{H}$; $\mathrm{H}_{\mathrm{ax}}$ ), 1.90 (dd, $J=8.9$ and $17.4 \mathrm{~Hz}, 1 \mathrm{H}$; H6 eq), 1.51 (s, $2 \mathrm{H} ; 2 \times \mathrm{NH}), 1.29\left(\mathrm{~s}, 3 \mathrm{H} ; \mathrm{CH}_{3}\right)$ and $1.25\left(\mathrm{~s}, 3 \mathrm{H} ; \mathrm{CH}_{3}\right) \mathrm{ppm} .{ }^{13} \mathrm{C}$ NMR (63 MHz, $\left.\mathrm{CDCl}_{3}\right)$ ס: $166.4(\mathrm{C}), 133.7(\mathrm{CH}), 131.5(\mathrm{C}), 109.1(\mathrm{C})$, $79.1(\mathrm{CH}), 71.5(\mathrm{CH}), 51.8(\mathrm{CH}), 49.3\left(\mathrm{OCH}_{3}\right), 30.0\left(\mathrm{CH}_{2}\right), 27.9\left(\mathrm{CH}_{3}\right)$ and $25.6\left(\mathrm{CH}_{3}\right) \mathrm{ppm}$. IR (ATR): $v=3364(\mathrm{NH})$ and $1710(\mathrm{CO}) \mathrm{cm}^{-1}$. MS (ESI) $m / z=228\left(\mathrm{MH}^{+}\right)$. HRMS calcd for $\mathrm{C}_{11} \mathrm{H}_{18} \mathrm{NO}_{4}\left(\mathrm{MH}^{+}\right): 228.1230$; found, 228.1229.

\footnotetext{
Methyl

(3R,4S,5R)-5-(naphth-2-yl)methylamino-3,4-( $O$ isopropyliden)cyclohex-1-ene-1-carboxylate (9b) - A suspension of amine 8 (103.5 mg, $0.46 \mathrm{mmol}), 4 \AA$ molecular sieves $(103 \mathrm{mg})$ and sodium acetate $(75.5 \mathrm{mg}, 0.92 \mathrm{mmol})$ in dry methanol $(2.3 \mathrm{~mL})$, at room temperature and under inert atmosphere, was treated with 2 naphthaldehyde $(72 \mathrm{mg}, 0.46 \mathrm{mmol})$ and sodium cyanoborohydride (58 $\mathrm{mg}, 0.92 \mathrm{mmol})$. The reaction mixture was stirred at room temperature for $18 \mathrm{~h}$ and then filtered. The filtrate and the washings were concentrated under reduced pressure. The resulting residue was purified by flash chromatography, eluting with $(50: 50)$ ethyl acetate/hexane, to give the amine $9 \mathrm{~b}(120.4 \mathrm{mg}, 72 \%)$, as a yellow oil. $[\alpha]_{\mathrm{D}}^{20}=-100.3^{\circ}$ (c = 1.4 in $\left.\mathrm{CHCl}_{3}\right) .{ }^{1} \mathrm{H}$ NMR $\left(300 \mathrm{MHz}, \mathrm{CDCl}_{3}\right): \delta=7.80(\mathrm{~m}, 3 \mathrm{H} ; 3 \times \mathrm{ArH}), 7.75$ (s, $1 \mathrm{H} ; \mathrm{ArH}), 7.46(\mathrm{~m}, 3 \mathrm{H} ; 3 \times \mathrm{ArH}), 6.91(\mathrm{~m}, 1 \mathrm{H} ; \mathrm{H} 2), 4.65(\mathrm{t}, J=4.1 \mathrm{~Hz}$ $1 \mathrm{H}, \mathrm{H} 3), 4.09(\mathrm{~m}, 1 \mathrm{H} ; \mathrm{H} 4), 4.08(\mathrm{~d}, J=13.7 \mathrm{~Hz}, 1 \mathrm{H}$; NCHH), 3.95 (d, J $=13.7 \mathrm{~Hz}, 1 \mathrm{H} ; \mathrm{NCHH}), 3.75\left(\mathrm{~s}, 3 \mathrm{H} ; \mathrm{OCH}_{3}\right), 2.91-2.82(\mathrm{~m}, 2 \mathrm{H}$; $\left.\mathrm{H} 5+\mathrm{H}_{\mathrm{ax}}\right), 2.19$ (br s, $\left.1 \mathrm{H} ; \mathrm{NH}\right), 2.15-2.05\left(\mathrm{~m}, 1 \mathrm{H} ; \mathrm{H6}_{\mathrm{eq}}\right), 1.38$ (s, $3 \mathrm{H}$
}

$\mathrm{CH}_{3}$ ) and $1.35\left(\mathrm{~s}, 3 \mathrm{H} ; \mathrm{CH}_{3}\right)$ ppm. ${ }^{13} \mathrm{C}$ NMR (75 MHz, $\left.\mathrm{CDCl}_{3}\right): \delta=166.7$ $(\mathrm{C}), 137.5(\mathrm{C}), 133.9(\mathrm{CH}), 133.4(\mathrm{C}), 132.7(\mathrm{C}), 131.7(\mathrm{C}), 128.2(\mathrm{CH})$, $127.7(2 \times \mathrm{CH}), 126.4(2 \times \mathrm{CH}), 126.0(\mathrm{CH}), 125.6(\mathrm{CH}), 109.4(\mathrm{C}), 77.5$ $(\mathrm{CH}), 71.8(\mathrm{CH}), 54.7(\mathrm{CH}), 52.1\left(\mathrm{OCH}_{3}\right), 51.5\left(\mathrm{NCH}_{2}\right), 28.0\left(\mathrm{CH}_{3}\right), 27.3$ $\left(\mathrm{CH}_{2}\right)$ and $25.9\left(\mathrm{CH}_{3}\right)$ ppm. IR (ATR): $\mathrm{v}=3259(\mathrm{NH})$ and $1718(\mathrm{CO}) \mathrm{cm}^{-1}$. MS (ESI) $m / z=368\left(\mathrm{MH}^{+}\right)$. HRMS calcd for $\mathrm{C}_{22} \mathrm{H}_{26} \mathrm{NO}_{4}\left(\mathrm{MH}^{+}\right)$: 368.1856; found, 368.1852

\section{Methyl} (3R,4S,5R)-3,4-dihydroxy-5-(naphth-2 yl)methylaminocyclohex-1-ene-1-carboxylate (10b) - A solution of acetal $9 \mathrm{~b}(117 \mathrm{mg}, 0.32 \mathrm{mmol})$ in ethanol $(2.2 \mathrm{~mL})$ and hydrochloric acid $(0.09 \mathrm{~mL}, 6 \mathrm{M})$ was heated at $60{ }^{\circ} \mathrm{C}$ for $4 \mathrm{~h}$. After cooling to room temperature, the solvent was removed under reduced pressure and the resulting residue was purified by flash chromatography, eluting with (10:90) methanol/dichloromethane, to give diol $10 \mathrm{~b}$ (71 $\mathrm{mg}, 69 \%)$, as a colorless oil. $[\alpha]_{\mathrm{D}}^{20}=-87.7^{\circ}\left(c=1.0\right.$ in $\left.\mathrm{CH}_{3} \mathrm{OH}\right) .{ }^{1} \mathrm{H} \mathrm{NMR}(250 \mathrm{MHz}$, $\left.\mathrm{CD}_{3} \mathrm{OD}\right): \delta=7.92(\mathrm{~s}, 1 \mathrm{H} ; \mathrm{ArH}), 7.76(\mathrm{~m}, 3 \mathrm{H} ; 3 \times \mathrm{ArH}), 7.52(\mathrm{~d}, J=8.3 \mathrm{~Hz}$, $1 \mathrm{H} ; \mathrm{ArH}), 7.40$ (dd, $J=3.0$ and $5.8 \mathrm{~Hz}, 2 \mathrm{H} ; 2 \times \mathrm{ArH}), 6.77(\mathrm{~d}, J=3.1 \mathrm{~Hz}$, $1 \mathrm{H} ; \mathrm{H} 2), 4.36(\mathrm{~d}, J=13.4 \mathrm{~Hz}, 1 \mathrm{H} ; \mathrm{CHH}), 4.29(\mathrm{~d}, J=13.4 \mathrm{~Hz}, 1 \mathrm{H}$ $\mathrm{CHH}), 4.22(\mathrm{~m}, 1 \mathrm{H} ; \mathrm{H} 3), 3.63\left(\mathrm{~s}, 3 \mathrm{H} ; \mathrm{OCH}_{3}\right), 3.35(\mathrm{~m}, 1 \mathrm{H} ; \mathrm{H} 4), 3.18(\mathrm{~m}$, $1 \mathrm{H} ; \mathrm{H} 5), 2.96\left(\mathrm{dd}, J=4.6\right.$ and $17.3 \mathrm{~Hz}, 1 \mathrm{H} ; \mathrm{H}_{\mathrm{eq}}$ ) and 2.40 (dd, $J=10.3$ and $16.6 \mathrm{~Hz}, 1 \mathrm{H}$; H6 ${ }_{\mathrm{ax}}$ ) ppm. ${ }^{13} \mathrm{C} \mathrm{NMR}\left(63 \mathrm{MHz}, \mathrm{CD}_{3} \mathrm{OD}\right): \delta=167.6(\mathrm{C})$, $137.7(\mathrm{CH}), 134.8(\mathrm{C}), 134.6(\mathrm{C}), 131.0(\mathrm{C}), 130.5(\mathrm{CH}), 130.0(\mathrm{CH})$ $129.1(\mathrm{CH}), 128.7(\mathrm{CH}), 127.9(\mathrm{CH}), 127.7(\mathrm{C}), 127.6(2 \times \mathrm{CH}), 70.6(\mathrm{CH})$, $66.4(\mathrm{CH}), 54.4\left(\mathrm{OCH}_{3}\right), 52.7(\mathrm{CH}), 50.0\left(\mathrm{CH}_{2}\right)$ and $28.6\left(\mathrm{CH}_{2}\right) \mathrm{ppm}$. IR (ATR): $v=3349(\mathrm{NH}+\mathrm{OH})$ and $1710(\mathrm{CO}) \mathrm{cm}^{-1}$. MS (ESI) $\mathrm{m} / \mathrm{z}=328$ $\left(\mathrm{MH}^{+}\right)$. HRMS calcd for $\mathrm{C}_{19} \mathrm{H}_{22} \mathrm{NO}_{4}\left(\mathrm{MH}^{+}\right)$: 328.1543; found, 328.1547.

Sodium

(3R,4S,5R)-3,4-dihydroxy-5-(naphth-2yl)methylaminocyclohex-1-ene-1-carboxylate (4b) - A solution of ester 10b $(65.3 \mathrm{mg}, 0.20 \mathrm{mmol})$ in THF $(2 \mathrm{~mL})$ was treated with an aqueous solution of sodium hydroxide $(0.4 \mathrm{~mL}, 0.20 \mathrm{mmol}, 0.5 \mathrm{M})$. The resulting mixture was stirred at room temperature for $30 \mathrm{~min}$ and then MilliQ water was added. The organic solvent was removed under reduced pressure and the resulting aqueous solution was washed with diethyl ether $(\times 2)$ and lyophilized to give the sodium salt $\mathbf{4 b}(64.3 \mathrm{mg}$, $96 \%)$, as a yellow foam. $[\alpha]_{\mathrm{D}}^{20}=-66.7^{\circ}\left(c=1.0\right.$ in $\left.\mathrm{CH}_{3} \mathrm{OH}\right) .{ }^{1} \mathrm{H}$ NMR $(250$ $\left.\mathrm{MHz}, \mathrm{CD}_{3} \mathrm{OD}\right): \delta=7.74(\mathrm{~m}, 4 \mathrm{H} ; 4 \times \mathrm{ArH}), 7.41(\mathrm{~m}, 1 \mathrm{H} ; \mathrm{ArH}), 7.35(\mathrm{~m}, 2$ $\mathrm{H} ; 2 \times \mathrm{ArH}), 6.47(\mathrm{~m}, 1 \mathrm{H} ; \mathrm{H} 2), 4.13(\mathrm{t}, J=4.2 \mathrm{~Hz}, 1 \mathrm{H} ; \mathrm{H} 3), 4.02$ (d, J = $13.0 \mathrm{~Hz}, 1 \mathrm{H}$; NCHH), 3.80 (d, $J=13.0 \mathrm{~Hz}, 1 \mathrm{H}$; NCHH), 3.46 (ddd, $J=$ 1.9, 4.4 and $10.3 \mathrm{~Hz}, 1 \mathrm{H} ; \mathrm{H} 4), 2.93(\mathrm{~m}, 2 \mathrm{H} ; \mathrm{H} 5+\mathrm{CH}-6)$ and $2.02(\mathrm{~m}, 1$ $\mathrm{H}$; CHH-6) ppm. ${ }^{13} \mathrm{C}$ NMR (63 MHz, CD $\left.{ }_{3} \mathrm{OD}\right): \delta=175.6(\mathrm{C}), 138.8(\mathrm{C})$, $138.3(\mathrm{C}), 134.9(\mathrm{C}), 134.2(\mathrm{C}), 131.2(\mathrm{CH}), 129.2(\mathrm{CH}), 128.7(\mathrm{CH})$, $128.6(\mathrm{CH}), 128.0(\mathrm{CH}), 127.7(\mathrm{CH}), 127.1(\mathrm{CH}), 126.7(\mathrm{CH}), 73.6(\mathrm{CH})$, $67.3(\mathrm{CH}), 53.8(\mathrm{CH}), 51.8\left(\mathrm{CH}_{2}\right)$ and $32.5\left(\mathrm{CH}_{2}\right)$ ppm. IR (ATR): $\mathrm{v}=$ $3301(\mathrm{NH}+\mathrm{OH})$ and $1644(\mathrm{CO}) \mathrm{cm}^{-1}$. MS (ESI) $\mathrm{m} / \mathrm{z}=336\left(\mathrm{MH}^{+}\right)$. HRMS calcd for $\mathrm{C}_{18} \mathrm{H}_{19} \mathrm{NNaO}_{4}\left(\mathrm{MH}^{+}\right)$: 336.1206; found, 336.1203.

\section{Methyl}

(3R,4S,5R)-5-(1H-indol-5-yl)methylamino-3,4-( $O$ isopropyliden)cyclohex-1-ene-1-carboxylate (9c) - A suspension of amine 8 (93 mg, $0.41 \mathrm{mmol}), 4 \AA$ molecular sieves $(93 \mathrm{mg})$ and sodium acetate $(67 \mathrm{mg}, 0.82 \mathrm{mmol})$ in dry metanol $(2.1 \mathrm{~mL})$, at room temperature and under inert atmosphere, was treated with indol-5-carboxaldehyde (59 $\mathrm{mg}, 0.41 \mathrm{mmol}$ ) and sodium cyanoborohydride $(51 \mathrm{mg}, 0.82 \mathrm{mmol})$. The resulting mixture was stirred at room temperature for $18 \mathrm{~h}$ and filtered. The filtrate and the washings were concentrated under reduced pressure. The resulting residue was purified by flash chromatography, eluting with (50:50) ethyl acetate/hexane, to give amine $9 \mathrm{c}$ (62 $\mathrm{mg}, 42 \%)$, as a colorless oil. $[\alpha]_{\mathrm{D}}^{20}=-87.3^{\circ}\left(c=1.1\right.$ in $\left.\mathrm{CHCl}_{3}\right) .{ }^{1} \mathrm{H}$ NMR $(300 \mathrm{MHz}$, $\left.\mathrm{CDCl}_{3}\right): \delta=8.37(\mathrm{br} \mathrm{s}, 1 \mathrm{H} ; \mathrm{NH}), 7.56(\mathrm{~s}, 1 \mathrm{H} ; \mathrm{ArH}), 7.32(\mathrm{~d}, J=8.3 \mathrm{~Hz}$, $\mathrm{H}$; ArH), $7.18(\mathrm{t}, J=3.0 \mathrm{~Hz}, 1 \mathrm{H}$; ArH), $7.13(\mathrm{~d}, J=8.4 \mathrm{~Hz}, 1 \mathrm{H}$; ArH), $6.91(\mathrm{~m}, 1 \mathrm{H} ; \mathrm{ArH}), 6.49(\mathrm{~m}, 1 \mathrm{H} ; \mathrm{H} 2), 4.65(\mathrm{~m}, 1 \mathrm{H} ; \mathrm{H} 3), 4.10(\mathrm{~m}, 1 \mathrm{H}$ $\mathrm{H} 4), 4.07$ (d, $J=13.0 \mathrm{~Hz}, 1 \mathrm{H}$; NCHH), $3.88(\mathrm{~d}, J=13.0 \mathrm{~Hz}, 1 \mathrm{H} ; \mathrm{NCH})$, 3.77 (s, $\left.3 \mathrm{H} ; \mathrm{OCH}_{3}\right), 2.95-2.82(\mathrm{~m}, 2 \mathrm{H} ; \mathrm{H} 5+\mathrm{H} 6 \mathrm{ax}), 2.29$ (br s, $1 \mathrm{H} ; \mathrm{NH}$ ) 
$2.12\left(\mathrm{dd}, J=6.8\right.$ and $\left.15.6 \mathrm{~Hz}, 1 \mathrm{H} ; \mathrm{H}_{\mathrm{eq}}\right), 1.37\left(\mathrm{~s}, 3 \mathrm{H} ; \mathrm{CH}_{3}\right)$ and 1.33 (s, $\left.3 \mathrm{H} ; \mathrm{CH}_{3}\right)$ ppm. ${ }^{13} \mathrm{C}$ NMR $\left(75 \mathrm{MHz}, \mathrm{CDCl}_{3}\right): \delta=166.9$ (C), 135.2 (C), $134.1(\mathrm{CH}), 131.8(\mathrm{C}), 130.9(\mathrm{C}), 128.1(\mathrm{C}), 124.7(\mathrm{CH}), 122.6(\mathrm{CH})$, $120.3(\mathrm{CH}), 111.2(\mathrm{CH}), 109.6(\mathrm{C}), 102.5(\mathrm{CH}), 77.4(\mathrm{CH}), 71.9(\mathrm{CH})$, $54.7(\mathrm{CH}), 52.2\left(\mathrm{OCH}_{3}\right), 52.0\left(\mathrm{NCH}_{2}\right), 28.1\left(\mathrm{CH}_{3}\right), 27.2\left(\mathrm{CH}_{2}\right)$ and 26.1 $\left(\mathrm{CH}_{3}\right) \mathrm{ppm}$. IR (ATR): $\mathrm{v}=3383(\mathrm{NH})$ and $1710(\mathrm{CO}) \mathrm{cm}^{-1}$. MS (ESI) $\mathrm{m} / \mathrm{z}$ $=357\left(\mathrm{MH}^{+}\right)$. HRMS calcd for $\mathrm{C}_{20} \mathrm{H}_{25} \mathrm{~N}_{2} \mathrm{O}_{4}\left(\mathrm{MH}^{+}\right)$: 357.1809; found, 357.1800

\section{Methyl}

(3R,4S,5R)-3,4-dihydroxy-5-(1H-indol-5yl)methylaminocyclohex-1-ene-1-carboxylate (10c) - A solution of acetal $9 \mathrm{c}(62.1 \mathrm{mg}, 0.17 \mathrm{mmol})$ in ethanol $(1.1 \mathrm{~mL})$ and hydrochloric acid $(0.05 \mathrm{~mL}, 6 \mathrm{M})$ was heated at $60{ }^{\circ} \mathrm{C}$ for $4 \mathrm{~h}$. After cooling to room temperature, the solvent was removed under reduced pressure and the resulting residue was purified by flash chromatography, eluting with $(10: 90)$ methanol/dichloromethane, to give diol $10 \mathrm{c}(33.8 \mathrm{mg}, 63 \%)$, as a yellow foam. $[\alpha]_{\mathrm{D}}^{20}=-136.6^{\circ}\left(c=1.1\right.$ in $\left.\mathrm{CH}_{3} \mathrm{OH}\right) .{ }^{1} \mathrm{H}$ NMR $(300 \mathrm{MHz}$, $\mathrm{CD}_{3} \mathrm{OD}$ ): $\delta=7.75(\mathrm{~s}, 1 \mathrm{H} ; \mathrm{ArH}), 7.49(\mathrm{~d}, J=8.3 \mathrm{~Hz}, 1 \mathrm{H} ; \mathrm{ArH}), 7.33(\mathrm{~s}, 1$ $\mathrm{H}$; ArH), $7.27(\mathrm{~d}, J=8.4 \mathrm{~Hz}, 1 \mathrm{H} ; \mathrm{ArH}), 6.94(\mathrm{~d}, J=4.0 \mathrm{~Hz}, 1 \mathrm{H}$; $\mathrm{ArH})$, $6.49(\mathrm{~d}, J=3.0 \mathrm{~Hz}, 1 \mathrm{H} ; \mathrm{H} 2), 4.46(\mathrm{~d}, J=13.6 \mathrm{~Hz}, 1 \mathrm{H} ; \mathrm{NCH}), 4.41(\mathrm{~d}, J$ $=13.6 \mathrm{~Hz}, 1 \mathrm{H} ; \mathrm{NCHH}), 4.34(\mathrm{~m}, 1 \mathrm{H} ; \mathrm{H} 3), 3.86(\mathrm{dd}, J=3.3$ and $11.0 \mathrm{~Hz}$, $1 \mathrm{H} ; \mathrm{H} 4), 3.79\left(\mathrm{~s}, 3 \mathrm{H} ; \mathrm{OCH}_{3}\right), 3.50(\mathrm{~m}, 1 \mathrm{H} ; \mathrm{H} 5), 3.09$ (dd, $J=5.5$ and $\left.17.3 \mathrm{~Hz}, 1 \mathrm{H} ; \mathrm{H6}_{\mathrm{ax}}\right)$ and 2.49 (dd, $J=2.9$ and $14.3 \mathrm{~Hz}, 1 \mathrm{H}$; H6 $\mathrm{Heq}_{\text {eq }}$ ppm. ${ }^{13} \mathrm{C}$ NMR (75 MHz, CD ${ }_{3} \mathrm{OD}$ ): $\delta=167.1(\mathrm{C}), 137.5(2 \times \mathrm{CH}), 129.9(\mathrm{C})$, $129.3(\mathrm{C}), 126.9(\mathrm{CH}), 123.4(\mathrm{CH}), 123.1(\mathrm{CH}), 121.9(\mathrm{C}), 112.8(\mathrm{CH})$, $102.4(\mathrm{C}), 70.0(\mathrm{CH}), 66.0(\mathrm{CH}), 53.5(\mathrm{CH}), 53.4\left(\mathrm{OCH}_{3}\right), 50.7\left(\mathrm{NCH}_{2}\right)$ and $28.3\left(\mathrm{CH}_{2}\right)$ ppm. IR (ATR): $v=3338(\mathrm{NH}+\mathrm{OH})$ and $1706(\mathrm{CO}) \mathrm{cm}^{-1}$. MS (ESI) $m / z=317\left(\mathrm{MH}^{+}\right)$. HRMS calcd for $\mathrm{C}_{17} \mathrm{H}_{21} \mathrm{~N}_{2} \mathrm{O}_{4}\left(\mathrm{MH}^{+}\right)$: 317.1496; found, 317.1499.

\section{Sodium}

(3R,4S,5R)-3,4-dihydroxy-5-(1 H-indol-5yl)methylaminocyclohex-1-ene-1-carboxylate (4c) - A solution of ester $10 \mathrm{c}(80.1 \mathrm{mg}, 0.25 \mathrm{mmol})$ in THF $(2.5 \mathrm{~mL})$ was treated with an aqueous solution of sodium hydroxide $(0.5 \mathrm{~mL}, 0.25 \mathrm{mmol}, 0.5 \mathrm{M})$. The resulting mixture was stirred at room temperature for $30 \mathrm{~min}$ and then MilliQ water was added. The organic solvent was removed under reduced pressure and the resulting aqueous solution was washed with diethyl ether $(\times 2)$ and lyophilized to give the sodium salt $4 \mathrm{c}(73.7 \mathrm{mg}$, $91 \%)$, as a yellow foam. $[\alpha]_{\mathrm{D}}^{20}=-54.1^{\circ}\left(c=1.0\right.$ in $\left.\mathrm{H}_{2} \mathrm{O}\right) .{ }^{1} \mathrm{H}$ NMR $(300$ $\left.\mathrm{MHz}, \mathrm{D}_{2} \mathrm{O}\right): \delta=7.54(\mathrm{~s}, 1 \mathrm{H} ; \mathrm{ArH}), 7.46(\mathrm{~d}, J=8.3 \mathrm{~Hz}, 1 \mathrm{H} ; \mathrm{ArH}), 7.34(\mathrm{~s}$, $1 \mathrm{H} ; \mathrm{ArH}), 7.14(\mathrm{~d}, J=8.3 \mathrm{~Hz}, 1 \mathrm{H} ; \mathrm{ArH}), 6.51(\mathrm{br} \mathrm{s}, 1 \mathrm{H} ; \mathrm{ArH}), 6.44(\mathrm{~d}, J$ $=3.1 \mathrm{~Hz}, 1 \mathrm{H} ; \mathrm{H} 2), 4.25(\mathrm{~m}, 1 \mathrm{H} ; \mathrm{H} 3), 3.86(\mathrm{~d}, J=12.7 \mathrm{~Hz}, 1 \mathrm{H} ; \mathrm{NCHH})$, $3.66(\mathrm{~d}, J=12.7 \mathrm{~Hz}, 1 \mathrm{H}$; NCHH), $3.59(\mathrm{dd}, J=3.7$ and $9.6 \mathrm{~Hz}, 1 \mathrm{H} ; \mathrm{H} 4)$, $2.90(\mathrm{~m}, 1 \mathrm{H} ; \mathrm{H} 5), 2.80$ (dd, $J=5.0$ and $17.6 \mathrm{~Hz}, 1 \mathrm{H} ; \mathrm{Hb}_{\mathrm{ax}}$ ) and $2.04(\mathrm{dd}$, $J=8.8$ and $17.6 \mathrm{~Hz}, 1 \mathrm{H}$; H6 eq $)$ ppm. ${ }^{13} \mathrm{C}$ NMR $\left(75 \mathrm{MHz}, \mathrm{D}_{2} \mathrm{O}\right): \delta=178.1$ (C), $139.3(\mathrm{C}), 137.5(\mathrm{C}), 132.8(\mathrm{CH}), 132.7(\mathrm{C}), 130.1(\mathrm{C}), 128.7(\mathrm{CH})$, $125.0(\mathrm{CH}), 122.8(\mathrm{CH}), 114.2(\mathrm{CH}), 103.5(\mathrm{CH}), 73.8(\mathrm{CH}), 68.3(\mathrm{CH})$, $54.4(\mathrm{CH}), 52.5\left(\mathrm{NCH}_{2}\right)$ and $32.6\left(\mathrm{CH}_{2}\right) \mathrm{ppm}$. IR $(\mathrm{ATR}): \mathrm{v}=3395(\mathrm{NH})$ $3286(\mathrm{OH})$ and $1654(\mathrm{CO}) \mathrm{cm}^{-1}$. MS (ESI) $\mathrm{m} / z=325\left(\mathrm{MH}^{+}\right)$. HRMS calcd for $\mathrm{C}_{16} \mathrm{H}_{18} \mathrm{~N}_{2} \mathrm{O}_{4} \mathrm{Na}\left(\mathrm{MH}^{+}\right)$: 325.1159; found, 325.1153 .

Methyl $\quad(3 R, 4 S, 5 R)-5$-amino-3,4-dihydroxycyclohex-1-ene-1carboxylate [methyl 5 -aminoshikimate] (11) - A solution of azide $6^{[4]}$ $(75 \mathrm{mg}, 0.35 \mathrm{mmol})$ in tetrahydrofuran $(8.8 \mathrm{~mL})$ and water $(0.085 \mathrm{~mL})$ was treated with triphenylphosphine $(101 \mathrm{mg}, 0.38 \mathrm{mmol})$. The resulting mixture was heated under reflux for $4 \mathrm{~h}$. After cooling to room temperature, the solvents were concentrated under reduced pressure. The resulting residue was purified by flash chromatography, eluting with $(20: 80)$ methanol/dichloromethane, to give the amine $11^{[6]}(50.2 \mathrm{mg}$, $77 \%)$, as a yellow solid. m.p., $149.8-150.1^{\circ} \mathrm{C}$. $[\alpha]_{\mathrm{D}}^{20}=-179.7^{\circ}(c=1.1 \mathrm{in}$ $\left.\mathrm{CH}_{3} \mathrm{OH}\right) .{ }^{1} \mathrm{H}$ NMR $\left(300 \mathrm{MHz}, \mathrm{CD}_{3} \mathrm{OD}\right): \delta=6.91(\mathrm{~m}, 1 \mathrm{H} ; \mathrm{H} 2), 4.33(\mathrm{t}, J=$ $4.4 \mathrm{~Hz}, 1 \mathrm{H} ; \mathrm{H} 3), 3.80\left(\mathrm{~s}, 3 \mathrm{H}\right.$; $\left.\mathrm{OCH}_{3}\right), 3.47$ (dd, $J=4.3$ and $9.8 \mathrm{~Hz}, 1 \mathrm{H}$; $\mathrm{H} 4$ ), 3.14 (td, $J=5.5$ and $9.4 \mathrm{~Hz}, 1 \mathrm{H} ; \mathrm{H} 5$ ), $2.83(\mathrm{dd}, J=5.4$ and $17.9 \mathrm{~Hz}$, $1 \mathrm{H} ; \mathrm{H}_{\mathrm{ax}}$ ) and 2.15-2.05 (ddd, $J=2.5,8.7$ and $17.9 \mathrm{~Hz}, 1 \mathrm{H} ; \mathrm{H}_{\mathrm{eq}}$ ) ppm.
${ }^{13} \mathrm{C}$ NMR $\left(75 \mathrm{MHz}, \mathrm{CD}_{3} \mathrm{OD}\right): \delta=168.5(\mathrm{C}), 138.2(\mathrm{CH}), 131.8(\mathrm{C}), 74.5$ $(\mathrm{CH}), 66.8(\mathrm{CH}), 52.5\left(\mathrm{OCH}_{3}\right), 48.3(\mathrm{CH})$ and $32.9\left(\mathrm{CH}_{2}\right) \mathrm{ppm}$. IR (ATR): $\mathrm{v}=3441(\mathrm{NH})$ and $1707(\mathrm{CO}) \mathrm{cm}^{-1}$. MS (ESI) $\mathrm{m} / \mathrm{z}=188\left(\mathrm{MH}^{+}\right)$. HRMS calcd for $\mathrm{C}_{8} \mathrm{H}_{14} \mathrm{NO}_{4}\left(\mathrm{MH}^{+}\right)$: 188.0917 ; found, 188.0916 .

Methyl $\quad(3 R, 4 S, 5 R)$-5-di(benzo[b]thiophen-5-yl)methylamino-3,4dihydroxycyclohex-1-eno-1-carboxylate (12a) - A solution of amine 11 $(106 \mathrm{mg}, 0.57 \mathrm{mmol}$ ) and anhydrous potassium carbonate $(94 \mathrm{mg}, 0.68$ $\mathrm{mmol})$ in dry acetonitrile $(2.9 \mathrm{~mL})$, under inert atmosphere, was treated with a solution of 5 -(bromomethyl)benzo[b]thiophene (129.4 mg, 0.57 $\mathrm{mmol})$ in dry acetonitrile $(3.2 \mathrm{~mL})$. The resulting mixture was stirred at room temperature for $18 \mathrm{~h}$ and then diluted with water and chloroform. The organic layer was separated and the aqueous phase was extracted with chloroform $(\times 2)$. The combined organic extracts were dried (anh. $\mathrm{Na}_{2} \mathrm{SO}_{4}$ ), filtered and concentrated under reduced pressure. The resulting residue was purified by flash chromatography, eluting with (30:70) ethyl acetate/hexane, to give dialkylamine $12 \mathrm{a}(87.4 \mathrm{mg}, 32 \%)$ as a colourless oil. $[\alpha]_{\mathrm{D}}^{20}=-71.1^{\circ}\left(c=1.2\right.$ in $\left.\mathrm{CHCl}_{3}\right) .{ }^{1} \mathrm{H}$ NMR $(250 \mathrm{MHz}$, $\left.\mathrm{CDCl}_{3}\right): \delta=7.80(\mathrm{~d}, J=8.2 \mathrm{~Hz}, 2 \mathrm{H} ; 2 \times \mathrm{ArH}), 7.67$ (br s, $\left.2 \mathrm{H} ; 2 \times \mathrm{ArH}\right)$, 7.41 (dd, $J=2.9$ and $5.4 \mathrm{~Hz}, 2 \mathrm{H} ; 2 \times A r H), 7.25(\mathrm{~m}, 4 \mathrm{H} ; 4 \times \mathrm{ArH}), 6.85$ (t, $J$ $=2.5 \mathrm{~Hz}, 1 \mathrm{H} ; \mathrm{H} 2), 4.40(\mathrm{br} \mathrm{s}, 1 \mathrm{H} ; \mathrm{H} 3), 4.10(\mathrm{~m}, 1 \mathrm{H} ; \mathrm{H} 4), 3.60(\mathrm{~d}, \mathrm{~J}=$ $13.0 \mathrm{~Hz}, 2 \mathrm{H} ; 2 \times \mathrm{NCHH}$ ), $3.76\left(\mathrm{~s}, 3 \mathrm{H} ; \mathrm{OCH}_{3}\right), 3.58(\mathrm{~d}, J=13.0 \mathrm{~Hz}, 2 \mathrm{H}$; $2 \times \mathrm{NCHH}$ ), $3.16(\mathrm{~m}, 1 \mathrm{H}, \mathrm{H} 5), 2.86\left(\mathrm{br} \mathrm{d}, J=9.3 \mathrm{~Hz}, 1 \mathrm{H}, \mathrm{H6}_{\mathrm{ax}}\right), 2.65(\mathrm{br} \mathrm{s}$ $1 \mathrm{H}, \mathrm{OH})$ and $2.34\left(\mathrm{~m}, 1 \mathrm{H} ; \mathrm{H}_{\text {eq }}\right)$ ppm. ${ }^{13} \mathrm{C} \mathrm{NMR}\left(63 \mathrm{MHz}, \mathrm{CDCl}_{3}\right): \delta=$ $167.1(\mathrm{C}), 139.9(\mathrm{CH}), 138.9(\mathrm{C}), 135.0(2 \times \mathrm{C}), 134.8(2 \times \mathrm{C}), 132.6(2 \times \mathrm{C})$, $127.0(2 \times \mathrm{CH}), 125.3(2 \times \mathrm{CH}), 124.1(2 \times \mathrm{CH}), 123.8(2 \times \mathrm{CH}), 122.9(2 \times \mathrm{CH})$, $68.1(\mathrm{CH}), 65.0(\mathrm{CH}), 53.9\left(2 \times \mathrm{NCH}_{2}\right), 53.6(\mathrm{CH}), 52.3\left(\mathrm{OCH}_{3}\right)$ and 22.5 $\left(\mathrm{CH}_{2}\right)$ ppm. IR (ATR): $\mathrm{v}=3409(\mathrm{OH})$ and $1707(\mathrm{CO}) \mathrm{cm}^{-1}$. MS (ESI) $\mathrm{m} / \mathrm{z}$ $=480\left(\mathrm{MH}^{+}\right)$. HRMS calcd for $\mathrm{C}_{26} \mathrm{H}_{26} \mathrm{NO}_{4} \mathrm{~S}_{2}\left(\mathrm{MH}^{+}\right)$: 480.1298; found, 480.1297

Sodium (3R,4S,5R)-5-di(benzo[b]thiophen-5-yl)methylamino-3,4dihydroxycyclohex-1-eno-1-carboxylate (5a) - A solution of ester 12a (25.1 mg, $0.052 \mathrm{mmol})$ in THF $(0.5 \mathrm{~mL})$ was treated with an aqueous solution of sodium hydroxide $(0.10 \mathrm{~mL}, 0.5 \mathrm{M})$. The resulting mixture was stirred at room temperature for $30 \mathrm{~min}$ and then MilliQ water was added. The organic solvent was removed under reduced pressure and the resulting aqueous solution was washed with diethyl ether $(\times 2)$ and lyophilized to give the sodium salt 5 a (24 mg, 94\%), as a white solid. m.p., 184.5-185.0 ${ }^{\circ} \mathrm{C}$. $[\alpha]_{\mathrm{D}}^{20}=-73.9^{\circ}\left(c=1.4\right.$ in $\left.\mathrm{CH}_{3} \mathrm{OH}\right) .{ }^{1} \mathrm{H}$ NMR $(250 \mathrm{MHz}$, $\left.\mathrm{CD}_{3} \mathrm{OD}\right): \delta=7.65(\mathrm{~m}, 4 \mathrm{H} ; 4 \times \mathrm{ArH}), 7.36(\mathrm{br} \mathrm{d}, J=5.3 \mathrm{~Hz}, 2 \mathrm{H} ; 2 \times \mathrm{ArH})$, $7.23(\mathrm{~d}, J=8.3 \mathrm{~Hz}, 2 \mathrm{H} ; 2 \times \mathrm{ArH}), 7.16(\mathrm{~m}, 2 \mathrm{H} ; 2 \times \mathrm{ArH}), 6.31(\mathrm{~m}, 1 \mathrm{H} ; \mathrm{H} 2)$, $4.13(\mathrm{~m}, 1 \mathrm{H}$; H3), 3.89 (d, J=13.0 Hz, $2 \mathrm{H}$; $2 \times \mathrm{NCH}), 3.66(\mathrm{~m}, 1 \mathrm{H} ; \mathrm{H} 4)$, $3.58(\mathrm{~d}, J=13.0 \mathrm{~Hz}, 2 \mathrm{H}$; $2 \times \mathrm{NCHH}$ ), 3.05 (m, $1 \mathrm{H}$; H5), 2.68 (dd, $J=4.5$ and $17.8 \mathrm{~Hz}, 1 \mathrm{H} ; \mathrm{H}_{\mathrm{eq}}$ ) and 2.28 (dd, $J=10.8$ and $17.8 \mathrm{~Hz}, 1 \mathrm{H} ; \mathrm{H} 6_{\mathrm{ax}}$ ) ppm. ${ }^{13} \mathrm{C}$ NMR $\left(63 \mathrm{MHz}, \mathrm{CD}_{3} \mathrm{OD}\right): \delta=175.8(\mathrm{C}), 141.2(2 \times \mathrm{C}), 140.5(\mathrm{C})$, $139.8(2 \times \mathrm{C}), 137.4(2 \times \mathrm{C}), 130.1(\mathrm{CH}), 127.6(2 \times \mathrm{CH}), 126.6(2 \times \mathrm{CH})$, $125.0(2 \times \mathrm{CH}), 124.8(2 \times \mathrm{CH}), 123.2(2 \times \mathrm{CH}), 71.4(\mathrm{CH}), 67.6(\mathrm{CH}), 55.0$ $\left(2 \times \mathrm{NCH}_{2}\right), 32.8(\mathrm{CH})$ and $14.5\left(\mathrm{CH}_{2}\right) \mathrm{ppm}$. IR $(\mathrm{ATR}): \mathrm{v}=3397(\mathrm{OH})$ and 1644 (CO) $\mathrm{cm}^{-1}$. MS (ESI) $\mathrm{m} / z=488\left(\mathrm{MH}^{+}\right)$. HRMS calcd for $\mathrm{C}_{25} \mathrm{H}_{23} \mathrm{NO}_{4} \mathrm{~S}_{2} \mathrm{Na}\left(\mathrm{MH}^{+}\right): 488.0961$; found, 488.0949

Methy

(3R,4S,5R)-5-di(naphth-2-yl)methylamino-3,4 dihydroxycyclohex-1-eno-1-carboxylate (12b) - A solution of amine 11 (103 $\mathrm{mg}, 0.55 \mathrm{mmol}$ ) and anhydrous potassium carbonate $(91.2 \mathrm{mg}$ $0.66 \mathrm{mmol})$ in dry acetonitrile $(2.8 \mathrm{~mL})$, under inert atmosphere, was treated with a solution of 5-(bromomethyl)naphthalene $(121.6 \mathrm{mg}, 0.55$ $\mathrm{mmol})$ in dry acetonitrile $(3.1 \mathrm{~mL})$. The resulting mixture was stirred at room temperature for $18 \mathrm{~h}$ and then diluted with water and chloroform. The organic layer was separated and the aqueous phase was extracted with chloroform $(\times 2)$. The combined organic extracts were dried (anh. $\mathrm{Na}_{2} \mathrm{SO}_{4}$ ), filtered and concentrated under reduced pressure. The resulting residue was purified by flash chromatography, eluting with (40:60) ethyl acetate/hexane, to give dialkylamine $12 \mathrm{~b}(80 \mathrm{mg}, 31 \%)$ as a 
white foam. $[\alpha]_{\mathrm{D}}^{20}=-96.4^{\circ}\left(c=1.1\right.$ in $\left.\mathrm{CH}_{3} \mathrm{OH}\right) .{ }^{1} \mathrm{H}$ NMR $(300 \mathrm{MHz}$ $\left.\mathrm{CD}_{3} \mathrm{OD}\right): \delta=7.72(\mathrm{~m}, 8 \mathrm{H} ; 8 \times \mathrm{ArH}), 7.44-7.35(\mathrm{~m}, 6 \mathrm{H} ; 6 \times \mathrm{ArH}), 6.70(\mathrm{dd}$, $J=1.9$ and $5.3 \mathrm{~Hz}, 1 \mathrm{H} ; \mathrm{H} 2), 4.23(\mathrm{t}, J=4.6 \mathrm{~Hz}, 1 \mathrm{H} ; \mathrm{H} 3), 3.88(\mathrm{~d}, J=$ $13.5 \mathrm{~Hz}, 2 \mathrm{H} ; 2 \times \mathrm{NCH}), 3.72\left(\mathrm{~s}, 3 \mathrm{H} ; \mathrm{OCH}_{3}\right), 3.59(\mathrm{~m}, 3 \mathrm{H} ; 2 \times \mathrm{NCHH}+\mathrm{H} 4)$ $3.14(\mathrm{td}, J=5.3$ and $10.6 \mathrm{~Hz}, 1 \mathrm{H} ; \mathrm{H} 5), 2.69(\mathrm{dd}, J=5.2$ and $17.9 \mathrm{~Hz}, 1$ $\mathrm{H} ; \mathrm{H}_{\text {ax }}$ ) and 2.20 (ddd, $J=1.9,10.6$ and $17.6 \mathrm{~Hz}, 1 \mathrm{H} ; \mathrm{H}_{\text {eq }}$ ) ppm. ${ }^{13} \mathrm{C}$ NMR $\left(75 \mathrm{MHz}, \mathrm{CD}_{3} \mathrm{OD}\right): \delta=168.5(\mathrm{C}), 138.5(2 \times \mathrm{C}), 136.9(\mathrm{CH}), 134.7$ $(2 \times \mathrm{C}), 134.2(2 \times \mathrm{C}), 133.2(\mathrm{C}), 129.0(2 \times \mathrm{CH}), 128.6(7 \times \mathrm{CH}), 128.0$ $(2 \times \mathrm{CH}), 126.9(2 \times \mathrm{CH}), 126.6(2 \times \mathrm{CH}), 70.9(\mathrm{CH}), 67.1(\mathrm{CH}), 55.1$ $\left(2 \times \mathrm{NCH}_{2}\right), 54.9(\mathrm{CH}), 52.5\left(\mathrm{OCH}_{3}\right)$ and $26.1\left(\mathrm{CH}_{2}\right)$ ppm. IR (ATR): $v=$ $3411(\mathrm{OH})$ and $1711(\mathrm{CO}) \mathrm{cm}^{-1}$. MS (ESI) $\mathrm{m} / z=468\left(\mathrm{MH}^{+}\right)$. HRMS calcd for $\mathrm{C}_{30} \mathrm{H}_{30} \mathrm{NO}_{4}\left(\mathrm{MH}^{+}\right)$: 468.2169; found, 468.2168.

\section{Sodium}

(3R,4S,5R)-5-di(naphth-2-yl)methylamino-3,4dihydroxycyclohex-1-eno-1-carboxylate $(5 b)$ - A solution of ester $12 b$ $(67 \mathrm{mg}, 0.14 \mathrm{mmol})$ in THF $(1.4 \mathrm{~mL})$ was treated with an aqueous solution of sodium hydroxide $(0.28 \mathrm{~mL}, 0.5 \mathrm{M})$. The resulting mixture was stirred at room temperature for $30 \mathrm{~min}$ and then MilliQ water was added. The organic solvent was removed under reduced pressure and the resulting aqueous solution was washed with diethyl ether $(\times 2)$ and lyophilized to give the sodium salt $\mathbf{5 b}(64.5 \mathrm{mg}, 97 \%)$, as a white solid. m.p., $161.8-162.0^{\circ} \mathrm{C}$. $[\alpha]_{\mathrm{D}}^{20}=-107.4^{\circ}\left(c=1.1\right.$ in $\left.\mathrm{CH}_{3} \mathrm{OH}\right) .{ }^{1} \mathrm{H}$ NMR $(300$ $\left.\mathrm{MHz}, \mathrm{CD}_{3} \mathrm{OD}\right): \delta=7.54(\mathrm{~m}, 8 \mathrm{H} ; 8 \times \mathrm{ArH}), 7.29(\mathrm{~d}, J=8.5 \mathrm{~Hz}, 2 \mathrm{H} ; 2 \times \mathrm{ArH})$ $7.19(\mathrm{~m}, 4 \mathrm{H} ; 4 \times \mathrm{ArH}), 6.28$ (dd, $J=1.7$ and $5.2 \mathrm{~Hz}, 1 \mathrm{H} ; \mathrm{H} 2), 4.09$ (t, $J=$ $4.6 \mathrm{~Hz}, 1 \mathrm{H}$; H3), $3.83(\mathrm{~d}, J=13.4 \mathrm{~Hz}, 2 \mathrm{H} ; 2 \times \mathrm{NCH}), 3.54(\mathrm{~m}, 3 \mathrm{H}$; $2 \times \mathrm{NCHH}+\mathrm{H} 4$ ), 3.01 (td, $J=5.2$ and $10.8 \mathrm{~Hz}, 1 \mathrm{H} ; \mathrm{H} 5$ ), 2.67 (dd, $J=5.0$ and $17.8 \mathrm{~Hz}, 1 \mathrm{H} ; \mathrm{Hb}_{\text {ax }}$ ) and 2.25 (ddd, $J=1.7,10.8$ and $17.8 \mathrm{~Hz}, 1 \mathrm{H}$; $\mathrm{H}_{\mathrm{eq}}$ ) ppm. ${ }^{13} \mathrm{C}$ NMR $\left(75 \mathrm{MHz}, \mathrm{CD}_{3} \mathrm{OD}\right): \delta=175.8(\mathrm{C}), 140.5$ (C), 138.7 $(2 \times \mathrm{C}), 134.8(2 \times \mathrm{C}), 134.2(2 \times \mathrm{C}), 130.0(\mathrm{CH}), 129.0(2 \times \mathrm{CH}), 128.6$ $(6 \times \mathrm{CH}), 128.1(2 \times \mathrm{CH}), 126.9(2 \times \mathrm{CH}), 126.5(2 \times \mathrm{CH}), 71.4(\mathrm{CH}), 67.6$ $(\mathrm{CH}), 55.3\left(2 \times \mathrm{NCH}_{2}\right), 55.2(\mathrm{CH})$ and $27.1\left(\mathrm{CH}_{2}\right) \mathrm{ppm}$. IR $(\mathrm{ATR}): \mathrm{v}=3380$ $(\mathrm{OH})$ and $1659(\mathrm{CO}) \mathrm{cm}^{-1}$. MS (ESI) $\mathrm{m} / \mathrm{z}=454\left(\mathrm{MH}^{+}\right)$. HRMS calcd for $\mathrm{C}_{29} \mathrm{H}_{28} \mathrm{NO}_{4}\left(\mathrm{MH}^{+}\right)$: 454.2013; found, 454.2012.

Methyl (3R,4S,5R)-5-di(3-bromo-1-tert-butoxycarbonyl-1 H-indol-5yl)methylamino-3,4-dihydroxycyclohex-1-eno-1-carboxylate (12d) A solution of amine $11(60 \mathrm{mg}, 0.32 \mathrm{mmol})$ and potassium carbonate (52 $\mathrm{mg}, 0.38 \mathrm{mmol})$ in dry acetonitrile $(1.6 \mathrm{~mL})$, under argon, was treated with a solution of tert-butyl 3-bromo-5-(bromomethyl)-1H-indole-1carboxylate $^{[23]}(99 \mathrm{mg}, 0.32 \mathrm{mmol})$ in dry acetonitrile $(1.8 \mathrm{~mL})$. The resulting mixture was stirred at room temperature for $18 \mathrm{~h}$. Water was added and the organic layer was separated. The aqueous layer was extracted with chloroform $(\times 2)$. The combined organic extracts were dried (anh. $\mathrm{Na}_{2} \mathrm{SO}_{4}$ ), filtered and concentrated under reduced pressure. The residue obtained was purified by flash chromatography, eluting $(30: 70)$ ethyl acetate/hexane, to give the dialkyl amine $12 \mathrm{~d}$ (59 $\mathrm{mg}, 23 \%$ ) as a colourless oil. $[\alpha]_{\mathrm{D}}^{20}=-56.4^{\circ}\left(c=1.2\right.$ in $\left.\mathrm{CHCl}_{3}\right) .{ }^{1} \mathrm{H}$ NMR $(300 \mathrm{MHz}$, $\left.\mathrm{CDCl}_{3}\right): \delta=8.08(\mathrm{~d}, J=8.2 \mathrm{~Hz}, 2 \mathrm{H} ; 2 \times \mathrm{ArH}), 7.61(\mathrm{~s}, 2 \mathrm{H} ; 2 \times \mathrm{ArH}), 7.37(\mathrm{~s}$ $2 \mathrm{H} ; 2 \times \mathrm{ArH}), 7.30$ (d, $J=8.2 \mathrm{~Hz}, 2 \mathrm{H} ; 2 \times \mathrm{ArH}), 6.88(\mathrm{~d}, J=4.0 \mathrm{~Hz}, 1 \mathrm{H}$; H2), 4.44 (br s, $1 \mathrm{H} ; \mathrm{H} 3), 4.02(\mathrm{~d}, \mathrm{~J}=13.0 \mathrm{~Hz}, 2 \mathrm{H} ; 2 \times \mathrm{NCHH}), 3.79$ (s, 3 $\left.\mathrm{H} ; \mathrm{OCH}_{3}\right), 3.73(\mathrm{~m}, 1 \mathrm{H} ; \mathrm{H} 4), 3.65(\mathrm{~d}, \mathrm{~J}=13.1 \mathrm{~Hz}, 2 \mathrm{H} ; 2 \times \mathrm{NCHH}), 3.17$ (m, $1 \mathrm{H} ; \mathrm{H} 5), 2.88$ (dd, $J=3.9$ and $17.2 \mathrm{~Hz}, 1 \mathrm{H} ; \mathrm{H}_{\mathrm{eq}}$ ), 2.67 (br s, $2 \mathrm{H}$; $2 \times \mathrm{OH}$ ), 2.38 (dd, $J=12.0$ and $16.4 \mathrm{~Hz}, 1 \mathrm{H} ; \mathrm{Hb}_{\mathrm{ax}}$ ) and $1.57(\mathrm{~s}, 9 \mathrm{H}$ $\left.3 \times \mathrm{CH}_{3}\right)$ ppm. ${ }^{13} \mathrm{C}$ NMR $\left(75 \mathrm{MHz}, \mathrm{CDCl}_{3}\right) \delta: 167.1$ (C), $148.9(2 \times \mathrm{C}), 135.0$ $(2 \times \mathrm{C}), 134.1(2 \times \mathrm{C}), 133.9(\mathrm{CH}), 132.6(\mathrm{C}), 129.7(2 \times \mathrm{C}), 126.4(2 \times \mathrm{CH})$ $125.3(2 \times \mathrm{CH}), 120.0(2 \times \mathrm{CH}), 115.6(2 \times \mathrm{CH}), 97.9(2 \times \mathrm{C}), 84.5(2 \times \mathrm{C}), 68.2$ $(\mathrm{CH}), 65.1(\mathrm{CH}), 54.2\left(2 \times \mathrm{NCH}_{2}\right), 54.0(\mathrm{CH}), 52.3\left(\mathrm{OCH}_{3}\right), 28.3\left(3 \times \mathrm{CH}_{3}\right)$ and $22.7\left(\mathrm{CH}_{2}\right) \mathrm{ppm}$. IR (ATR): $\mathrm{v}=3463(\mathrm{OH}), 3150(\mathrm{NH}), 1738(\mathrm{CO})$ and $1717(\mathrm{CO}) \mathrm{cm}^{-1}$. MS (ESI) $\mathrm{m} / z=802$ and $804\left(\mathrm{MH}^{+}\right)$. HRMS calcd for $\mathrm{C}_{36} \mathrm{H}_{42} \mathrm{~N}_{3} \mathrm{O}_{8} \mathrm{Br}_{2}{ }^{79}\left(\mathrm{MH}^{+}\right)$: 802.1333; found, 802.1329.

(3R,4S,5R)-5-di(3-bromo-1H-indol-5-yl)methylamino-3,4dihydroxycyclohex-1-eno-1-carboxylic acid (5d) - A solution of ester 12d $(61.2 \mathrm{mg}, 0.095 \mathrm{mmol})$ and potassium carbonate $(39.4 \mathrm{mg}, 0.28$ $\mathrm{mmol})$ in $75 \%$ aqueous methanol $(1.4 \mathrm{~mL})$ was heated under reflux for $2.5 \mathrm{~h}$. After cooling to room temperature, diethyl ether was added and the organic layer was separated. The aqueous phase was washed with diethyl ether $(\times 2)$. The aqueous extract was lyophilized to give acid $\mathbf{5 d}$ (42 mg, $75 \%$ ) as a white foam. $[\alpha]_{\mathrm{D}}^{20}=-52.8^{\circ}\left(c=1.1\right.$ in $\left.\mathrm{CH}_{3} \mathrm{OH}\right) .{ }^{1} \mathrm{H}$ $\operatorname{NMR}\left(300 \mathrm{MHz}, \mathrm{CD}_{3} \mathrm{OD}\right.$ ): $\delta=7.35$ (br s, $\left.2 \mathrm{H} ; 2 \times \mathrm{ArH}\right), 7.26(\mathrm{~d}, J=8.4 \mathrm{~Hz}$, $2 \mathrm{H} ; 2 \times \mathrm{ArH}), 7.17(\mathrm{~s}, 2 \mathrm{H} ; 2 \times \mathrm{ArH}), 7.13(\mathrm{~d}, J=8.6 \mathrm{~Hz}, 2 \mathrm{H} ; 2 \times \mathrm{ArH}), 6.39$ (d, $J=5.1 \mathrm{~Hz}, 1 \mathrm{H} ; \mathrm{H} 2), 4.21(\mathrm{t}, J=4.7 \mathrm{~Hz}, 1 \mathrm{H} ; \mathrm{H} 3), 3.93(\mathrm{~d}, J=13.0 \mathrm{~Hz}$, $2 \mathrm{H} ; 2 \times \mathrm{NCHH}$ ), 3.65 (dd, $J=4.2$ and $11.0 \mathrm{~Hz}, 1 \mathrm{H} ; \mathrm{H} 4), 3.57$ (d, $J=13.1$ $\mathrm{Hz}, 2 \mathrm{H} ; 2 \times \mathrm{NCHH}$ ), 3.15 (td, $J=6.0$ and $13.0 \mathrm{~Hz}, 1 \mathrm{H} ; \mathrm{H} 5$ ), 2.76 (dd, $J=$ 6.1 and $21.4 \mathrm{~Hz}, 1 \mathrm{H}$; H6eq ) and 2.35 (dd, $J=12.5$ and $21.4 \mathrm{~Hz}, 1 \mathrm{H}$; $\left.\mathrm{H}_{\text {ax }}\right)$ ppm. ${ }^{13} \mathrm{C}$ NMR $\left(75 \mathrm{MHz}, \mathrm{CD}_{3} \mathrm{OD}\right): \delta=175.8(\mathrm{C}), 140.6(2 \times \mathrm{C})$, $136.4(2 \times \mathrm{C}), 132.5(2 \times \mathrm{C}), 129.9(\mathrm{CH}), 127.9(\mathrm{C}), 125.3(2 \times \mathrm{CH}), 124.8$ $(2 \times \mathrm{CH}), 119.8(2 \times \mathrm{CH}), 112.9(2 \times \mathrm{CH}), 90.7(2 \times \mathrm{C}), 70.8(\mathrm{CH}), 67.1(\mathrm{CH})$, $54.9\left(2 \times \mathrm{NCH}_{2}\right), 54.8(\mathrm{CH})$ and $25.8\left(\mathrm{CH}_{2}\right) \mathrm{ppm}$. IR (ATR): $\mathrm{v}=3333$ $(\mathrm{OH}+\mathrm{NH})$ and $1560(\mathrm{CO}) \mathrm{cm}^{-1}$. MS $(\mathrm{ESI}) \mathrm{m} / \mathrm{z}=585$ and $587(\mathrm{M}-\mathrm{H})$. HRMS calcd for $\mathrm{C}_{25} \mathrm{H}_{22} \mathrm{~N}_{3} \mathrm{O}_{8} \mathrm{Br}_{2}{ }^{79}(\mathrm{M}-\mathrm{H})$ : 585.9983 ; found, 585.9984 .

Shikimate kinase assay. Both enzymes were purified and assayed as described previously. ${ }^{15,27,23}$ The determined kinetic parameters for $\mathrm{Hp}$-SK and $M t-S K$ were $K_{m}(1)=39 \pm 8 \mu \mathrm{M} ; k_{\text {cat }}=116 \pm 410^{-3} \mathrm{~s}^{-1}$ and $K_{m}(1)=$ $544 \pm 14 \mu \mathrm{M} ; k_{\text {cat }}=295 \pm 8 \mathrm{~s}^{-1}$, respectively.

Docking studies. They were carried out using program GOLD $5.2^{[25]}$ and the enzyme geometries and the enzyme coordinates collected in the MD simulation studies carried out with the SK complex containing: (a) MtSK/ATP/Mg ${ }^{+2} /(6 R)-6$-hydroxyshikimic acid $(10 \mathrm{~ns})^{[23]}$; (b) Hp-SK/ADP/2 $(50 \mathrm{~ns})^{[24]}$. Different snapshots obtained after $\sim 7 \mathrm{~ns}$ of MD for $\mathrm{Mt}$-SK and $\sim 11 \mathrm{~ns}$ for $\mathrm{Hp}$-SK were employed. Water molecules, the product and (6R)-6-hydroxyshikimic acid were removed from the models. Ligand geometries were minimized using the AM1 Hamiltonian as implemented in the program Gaussian $09^{[28]}$ and used as MOL2 files. Each ligand was docked in 25 independent genetic algorithm (GA) runs, and for each of these a maximum number of $100000 \mathrm{GA}$ operations were performed on a single population of 50 individuals. Operator weights for crossover, mutation and migration in the entry box were used as default parameters (95, 95, and 10 , respectively), as well as the hydrogen bonding (4.0 $\AA$ ) and van der Waals $(2.5 \AA)$ parameters. The position of shikimate-3phosphate (2) and (6R)-6-hydroxyshikimic acid in both models was used to define the active-site and the radius was set to $7 \AA$. The "flip ring corners" flag was switched on, while all the other flags were off. The GOLD scoring function was used to rank the ligands in order to fitness.

Molecular Dynamics Simulations. Ligand preparation. The ligand geometries of the highest score solution obtained by docking were minimized using a restricted Hartree-Fock (RHF) method and a 6$31 \mathrm{G}(\mathrm{d})$ basis set, as implemented in the ab initio program Gaussian 09. Ligands were manually docked into the active site. The resulting wavefunctions were used to calculate electrostatic potential-derived (ESP) charges employing the restrained electrostatic potential (RESP) ${ }^{[29]}$ methodology, as implemented in the assisted model building with energy refinement (AMBER ${ }^{[30]}$ suite of programs. The missing bonded and nonbonded parameters were assigned, by analogy or through interpolation, from those already present in the AMBER database (GAFF). ${ }^{[31]}$

Generation and minimization of ternary complexes. Simulations of inhibitor/ATP/SK complexes were carried out using the highest score solution obtained by docking and the enzyme geometries used in those docking studies. Computation of the protonation state of titratable groups at $\mathrm{pH} 7.0$ was carried out using the $\mathrm{H}^{++}$Web server. ${ }^{[32]}$ Addition of hydrogen and molecular mechanics parameters from the ff03 and GAFF force fields, respectively, were assigned to the protein and the ligands using the LEaP module of AMBER Tools 14..$^{[30-31,33]}$ ATP and $\mathrm{Mg}^{2+}$ parameters used with the AMBER force field were included. ${ }^{[34-35]}$ 
The complex was immersed in a truncated octahedron of $~ 5200$ TIP3P water molecules and neutralized by addition of chloride (Mt-SK) or sodium (Hp-SK) ions. ${ }^{[30,36-37]}$ All systems were minimized in four stages: (a) initial minimization of the ligand and the closest residues of the SB domain (500 steps, first half using steepest descent and the rest using conjugate gradient); (b) minimization of the solvent and ions (5000 steps, first half using steepest descent and the rest using conjugate gradient); (c) minimization of the side chains, waters and ions (5000 steps, first half using steepest descent and the rest using conjugate gradient); (d) final minimization of the whole system (5000 steps, first half using steepest descent and the rest using conjugate gradient). A positional restraint force of $50 \mathrm{kcal} \mathrm{mol}^{-1} \AA^{-2}$ was applied to those unminimized atoms during the first three stages $(a-c)$.

Simulations. MD simulations were performed using the sander module from the AMBER 12 suite of programs. Periodic boundary conditions were applied and electrostatic interactions were treated using the smooth particle mesh Ewald method $(\mathrm{PME})^{[38]}$ with a grid spacing of $1 \AA$. The cutoff distance for the non-bonded interactions was $9 \AA$. The SHAKE algorithm ${ }^{[39]}$ was applied to all bonds containing hydrogen, using a tolerance of $10^{-5} \AA$ and an integration step of $2.0 \mathrm{fs}$. The minimized system was then heated at $300 \mathrm{~K}$ at $1 \mathrm{~atm}$ by increasing the temperature from $0 \mathrm{~K}$ to $300 \mathrm{~K}$ over $100 \mathrm{ps}$ and by keeping the system at $300 \mathrm{~K}$ another $100 \mathrm{ps}$. A positional restraint force of $50 \mathrm{kcal} \mathrm{mol}^{-1} \AA^{-2}$ was applied to all $\alpha$ carbons during the heating stage. Finally, an equilibration of the system at constant volume (100 ps with positional restraints of 5 $\mathrm{kcal} \mathrm{mol}{ }^{-1} \AA^{-2}$ to $\alpha$ alpha carbons) and constant pressure (another $100 \mathrm{ps}$ with positional restraints of $5 \mathrm{kcal} \mathrm{mol}^{-1} \AA^{-2}$ to $\alpha$ alpha carbons) were performed. The positional restraints were gradually reduced from 5 to 1 $\mathrm{mol}^{-1} \AA^{-2}$ (5 steps, $100 \mathrm{ps}$ each), and the resulting systems were allowed to equilibrate further $(100 \mathrm{ps})$. Unrestrained MD simulations were carried out for $50 \mathrm{~ns}$. System coordinates were collected every $10 \mathrm{ps}$ for further analysis. Figures depicting structures were prepared using PYMOL. ${ }^{[40]}$ The cpptraj module in AMBER 12 was used to analyze the trajectories and to calculate the root-mean-square deviations (RMSD) of the protein and ligands during the simulation. ${ }^{[4]}$

Vibrational Modes Calculations. The vibrational modes for the two SK enzyme were calculated by principal component analysis with the cpptraj module implemented in Amber Tools 14 from the corresponding MD trajectories of product release $\left(\mathrm{SK} / \mathrm{ADP} / \mathbf{2}^{[23-24]}\right) \cdot{ }^{[42]}$ The main vibrational modes for the two SK are shown in Figures $3 \mathrm{E}$ and $3 \mathrm{~F}$. The probability density of the vibrational modes obtained is shown in Figure S3.

MM/PBSA Calculations. The binding free energy for each ligand was calculated by the MM/PBSA ${ }^{26}$ approach implemented in Amber Tools 14 and based on the 451 snapshots extracted every 100 ps from the corresponding $50 \mathrm{~ns} \mathrm{MD}$ trajectories (SK/ATP/Mg ${ }^{2+} /$ ligand). Only the last $45 \mathrm{~ns}$ of the simulation were used. The Poisson-Boltzmann (PB) and Generalized Born (GB) implicit solvation models were employed. The latter model provided relative free energy values more in agreement with the relative inhibitory potency obtained experimentally. ante-MMPBSA.py module was used to create topology files for the complex, receptor and ligand and binding free energies were calulated with the MMPBSA.py module.

\section{Acknowledgements}

Financial support from the Spanish Ministry of Economy and Competiveness (SAF2013-42899-R), Xunta de Galicia (GRC2013-041) and the European Regional Development Fund (ERDF) is gratefully acknowledged. VP thanks the Spanish
Ministry of Economy and Competiveness for her FPU fellowship. EL thanks the Xunta de Galicia for his postdoctoral fellowship. We are grateful to the Centro de Supercomputación de Galicia (CESGA) for use of the SVG computer.

Keywords: Enzyme Motion • Inhibitors • Molecular Dynamics Simulations • Antibiotics $•$ Kinases

\section{References}

[1] M. A. Fischbach, C. T. Walsh, Science 2009, 325, 1089-1093.

[2] E. D. Brown, G. D. Wright, Nature 2016, 529, 336-343.

[3] K. M. Overby, J. F. Barrett, Drug Discov. Today 2005, 10, 45-52.

[4] D. Brown, Nature Rev. Drug Discov. 2015, 14, 821-832.

[5] R. J. Fair, Y. Tor, Perspect. Medicin. Chem. 2014, 6, 25-64.

[6] M. F. Chellat, L. Raguž, R. Reidl, Angew. Chem. Int. Ed. 2016, 55, 6600-6626.

[7] G. D. Wright, Chem. Biol. 2012, 19, 3-10

[8] J. Davies, D. Davies, Microbiol. Mol. Rev. 2010, 74, 417-433.

[9] S. J. Projan, Curr. Opin. Microbiol. 2003, 6, 427-430.

[10] P. Fernandes, Curr. Opin. Pharm. 2015, 24, 7-11.

[11] V. M. D Costa, C. E. King, L. Kalan, M. Morar, W. W. L. Sung, C. Schwarz, D. Froese, G. Zazula, F. Calmels, R. Debruyne, G. B. Golding, H. N. Poinar, G. D. Wright, Nature 2011, 477, 457-461.

[12] C. González-Bello, Curr. Top. Med. Chem. 2016, 16, 960-977.

[13] DEG: Data base of essential gene, http://www.essentialgene.org/

[14] G. Lamichhane, J. S. Freundlich, S. Ekins, N. Wickramaratne, S. T Nolan, W. R. Bisha, mBio 2011, 2, e00301.

[15] V. Prado, E. Lence, J. A. Vallejo, A. Beceiro, P. Thompson, A. R Hawkins, C. González-Bello, Chem. Eur. J. 2016, 22, 2758-2768.

[16] S. Gordon, J. Simithy, D. C. Goodwin, A. I. Calderón, Perspect. Medicin Chem. 2015, 7, 9-20.

[17] C. Han, J. Zhang, L. Chen, K. Chen, X. Shen, H. Jiang, Bioorg. Med Chem. 2007, 15, 656-662.

[18] M. Kumar, S. Verma, S. Sharma, A. Srinivasan, T. P. Singh, P. Kaur Chem. Bio. Drug Des. 2010, 76, 277-284.

[19] A. Segura-Cabrera, M. A. Rodríguez-Pérez, Bioorg. Med. Chem. Lett. 2008, 18, 3152-3157.

[20] M. D. Hartmann, G. P. Bourenkov, A. Oberschall, N. Strizhov, H. D Bartunik, J. Mol. Biol. 2006, 364, 411-423.

[21] W.-C. Cheng, Y.-N. Chang, W.-C. Wang, J. Bacteriol. 2005, 187, 8156-8163.

[22] W.-C. Cheng, Y.-F. Chen, H.-J. Wang, K.-C. Hsu, S.-C. Lin, T.-J. Chen, J.-M. Yang, W.-C. Wang, PLOS ONE 2012, 7, e33481.

[23] V. Prado, E. Lence, M. Maneiro, J. C. Vázquez-Ucha, A. Beceiro, P. Thompson, A. R. Hawkins, C. González-Bello, J. Med. Chem. 2016, 59, 5471-5487.

[24] B. Blanco, V. Prado, E. Lence, J. M. Otero, C. Garcia-Doval, M. J. van Raaij, A. L. Llamas-Saiz, H. Lamb, A. R. Hawkins, C. González-Bello, J. Am. Chem. Soc. 2013, 135, 12366-12376.

[25] http://www.ccdc.cam.ac.uk/products/life sciencies/gold/

[26] B. R. Miller III, T. D. McGee Jr., J. M. Swails, N. Homeyer, H. Gohlke, A. E. Roitberg, J. Chem. Theory Comput. 2012, 8, 3314-3321.

[27] T. Krell, J. Maclean, D. J. Boam, A. Cooper, M. Resmini, K. Brocklehurst, S. M. Kelly, N. C. Price, A. J. Lapthorn, J. R. Coggins Protein Science 2001, 10, 1137-1149.

[28] M. J. Frisch, G. W. Trucks, H. B. Schlegel, G. E. Scuseria, M. A. Robb, J. R. Cheeseman, G. Scalmani, V. Barone, B. Mennucci, G. A Petersson, H. Nakatsuji, M. Caricato, X. Li, H. P. Hratchian, A. F. Izmaylov, J. Bloino, G. Zheng, J. L. Sonnenberg, M. Hada, M. Ehara, K Toyota, R. Fukuda, J. Hasegawa, M. Ishida, T. Nakajima, Y. Honda, O. Kitao, H. Nakai, T. Vreven, J. A. Montgomery, Jr., J. E. Peralta, F Ogliaro, M. Bearpark, J. J. Heyd, E. Brothers, K. N. Kudin, V. N. 
Staroverov, R. Kobayashi, J. Normand, K. Raghavachari, A. Rendell, J. C. Burant, S. S. lyengar, J. Tomasi, M. Cossi, N. Rega, J. M. Millam, M. Klene, J. E. Knox, J. B. Cross, V. Bakken, C. Adamo, J. Jaramillo, R. Gomperts, R. E. Stratmann, O. Yazyev, A. J. Austin, R. Cammi, C Pomelli, J. W. Ochterski, R. L. Martin, K. Morokuma, V. G. Zakrzewski, G. A. Voth, P. Salvador, J. J. Dannenberg, S. Dapprich, A. D. Daniels, Ö. Farkas, J. B. Foresman, J. V. Ortiz, J. Cioslowski, and D. J. Fox, Gaussian 09, Revision D.01, Gaussian, Inc.: Wallingford CT, 2009.

[29] W. D. Cornell, P. Cieplak, C. I. Bayly, I. R. Gould, K. M. Merz, D. M. Ferguson, D. C. Spellmeyer, T. Fox, J. W. Caldwell, P. A. Kollman, J. Am. Chem. Soc. 1995, 117, 5179-5197.

[30] D. A. Case, T. E. Cheatham, T. Darden, H. Gohlke, R. Luo, K. M. Merz, O. Onufriev, C. Simmerling, B. Wang, R. J. Woods, J. Comput. Chem. 2005, 26, 1668-1688.

[31] (a) J. Wang, R. M. Wolf, J. W. Caldwell, P. A. Kollman, D. A. Case, J. Comp. Chem. 2004, 25, 1157-1174. (b) J. Wang, W. Wang, P. A. Kollman, D. A. Case, J. Mol. Graphics Modell. 2006, 25, 247-260.

[32] (a) J. C. Gordon, J. B. Myers, T. Folta, V. Shoja, L. S. Heath, A. Onufriev, Nucleic Acids Res 2005, 33 (Web Server issue):W368-W371. (b) http://biophysics.cs.vt.edu/H++.

[33] D. A. Case, J. T. Berryman, R. M. Betz, D. S. Cerutti, T. E. Cheatham, III, T. A. Darden, R. E. Duke, T. J. Giese, H. Gohlke, A. W. Goetz, N. Homeyer, S. Izadi, P. Janowski, J. Kaus, A. Kovalenko, T. S. Lee, S. LeGrand, P. Li, T. Luchko, R. Luo, B. Madej, K. M. Merz, G. Monard, P. Needham, H. Nguyen, H. T. Nguyen, I. Omelyan, A. Onufriev, D. R
Roe, A. Roitberg, R. Salomon-Ferrer, C. L. Simmerling, W. Smith, J Swails, R. C. Walker, J. Wang, R. M. Wolf, X. Wu, D. M. York and P. A Kollman (2015), AMBER 2015, AMBER 2015, Amber Tools 1.5; University of California, San Francisco.

[34] $\mathrm{Mg}^{2+}$ parameters used with the AMBER force field were downloaded from http://www.pharmacy.manchester.ac.uk/bryce/amber/. O. Allnér, L. Nilsson, A. Villa, J. Chem. Theory Comput. 2012, 8, 1493-1502.

[35] ATP parameters used with the AMBER force field were downloaded from http://www.pharmacy.manchester.ac.uk/bryce/amber/. K. L. Meagher, L. T. Redman, H. A. Carlson, J. Comput. Chem. 2003, 24, 1016-1025.

[36] J. Aqvist, J. Phys. Chem. 1990, 94, 8021-8024.

[37] W. L. Jorgensen, J. Chandrasekhar, J. D. Madura, J. Chem. Phys. 1983, 79, 926

[38] T. A. Darden, D. York, L. G. Pedersen, J. Chem. Phys. 1993, 98, 10089-10092

[39] J.-P. Ryckaert, G. Ciccotti, H. J. C. Berendsen, J. Comput. Phys. 1977, 23, 327-341.

[40] W. L. DeLano, The PyMOL Molecular Graphics System; DeLano Scientific LLC: Palo Alto, CA, 2008; http://www.pymol.org/

[41] D. R. Roe, T. E. Cheatham, J. Chem. Theory Comput. 2013, 9, 3084-3095.

[42] http://www.amber.utah.edu/AMBER-workshop/London-2015/pca/ 


\section{Entry for the Table of Contents}

\section{FULL PAPER}

Enzyme dynamics: The asynchronous and more reduced opening and its more parsimonious motion of the shikimic acid domain of the Helicobacter pylori enzyme for catalytic turnover were exploited for inhibitor design selectivity.

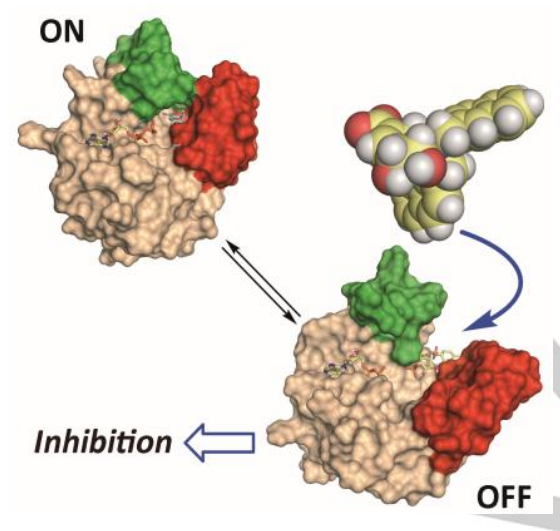

Verónica Prado, Emilio Lence, Paul Thompson, Alastair R. Hawkins and Concepción González-Bello*

Page No. - Page No.

Freezing the Dynamic Gap for Selectivity - Motion-based Design of Inhibitors of the Shikimate Kinase Enzyme 